$$
\text { DrE/OR/22365-T.T2 }
$$

\title{
The Clinch Bend Regional Industrial Site and Economic Development Opportunities
}

\author{
RIECEIVED
}

\author{
JAN 0419900 \\ OSTI
}

\section{DISCLAIMER}

This report was prepared as an account of work sponsored by an agency of the United States Government. Neither the United States Government nor any agency thereof, nor any of their employees, makes any warranty, express or implied, or assumes any legal liability or responsibility for the accuracy, completeness, or usefulness of any information, apparatus, product, or process disclosed, or represents that its use would not infringe privately owned rights. Reference herein to any specific commercial product, process, or service by trade name, trademark, manufacturer, or otherwise does not necessarily constitute or imply its endorsement, recommendation, or favoring by the United States Government or any agency thereof. The views and opinions of authors expressed herein do not necessarily state or reflect those of the United States Government or any agency thereof.

\section{LOCKWOOD GREENE}

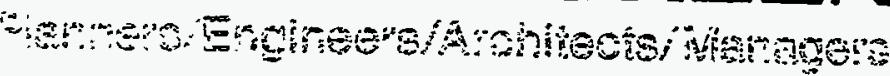

\section{MASTER}

DISTRIBUTION OF THUS DOCLMENT IS UALHATED 


\section{Table of Contents}

1. Introduction and Executive Summary

Page

Project Overview

Conclusions and Recommendations

Next Steps

2. Overview of Existing Industrial Facilities

Background

Oak Ridge Industrial Sites

Regional Industrial Sites and Parks $\quad 15$

Greenfield Opportunities 19

Industrial Land Absorption Rates $\quad 22$

3. Site Assets and Liabilities

Objectives 26

Perspectives on the Important Site Issues 27

The Corporate Location Decision Process 29

Corporate Site Selection Criteria 30

Assessment of Oak Ridge Industrial Sites 31

Conclusion - Clinch Bend Site Marketability 43

4. Recommended Site Improvements

Existing Site Infrastructure and Investment 52

Site Configuration and Development Sequencing 53

Recommended Additional Infrastructure and Site Improvements 55 Investment Costs and Revenues 57

Alternative Investment Strategy 61 


\section{Project Overview}

Oak Ridge, Tennessee is an attractive community of 27,000 residents located within the greater Knoxville metropolitan area. It contains the highest concentration of technical, management and degreed scientific talent in eastern Tennessee. Over the years it has proven to be an excellent place to live and work, and businesses have generally prospered in an affordable operating cost environment.

Residents enjoy a choice of urban, suburban and rural lifestyles and have easy access to cultural amenities and major educational and medical institutions. This diversity has proven to be ideal for many of the people attracted to work and raise a family near Oak Ridge, as demonstrated by a willingness to remain in the area after retirement.

The Oak Ridge economy is driven in part by major federal facilities that employ large numbers of engineers and scientists, the vendors supporting these facilities, and ancillary developments. Realizing that the continuance of federal programs is not assured, the community's lead economic development agency, the Oak Ridge Chamber of Commerce, has taken a proactive stand in planning for the region's future economic vitality.

Downsizing of the DOE operations in Oak Ridge prompted a search for economic development approaches capable of mitigating the potentially large economic and employment impacts. The East Tennessee Economic Council with the support of the Oak Ridge Chamber of Commerce undertook an assessment of the regional economic impacts and developed a set of strategies for regional economic adjustment i.e.. new job creation, economic base diversification, and reduced dependence on federal defense spending. Based on the occupational and skills characteristics of the dislocated work force, expanding existing manufacturing industries and recruiting new major manufacturing industries emerged as key regional economic adjustment strategies.

Consequently, the Chamber approached the Economic Development Administration (EDA) for assistance in developing the 1,200 acre, former site of the Clinch River Breeder Reactor project located in the Roane County portion of Oak Ridge. Since the cancellation of the Breeder Project in the 1970s, this site has been recognized as one of the major potential sites in the State of Tennessee for the location of a large private sector industrial facility. Over the past fifteen years, the Breeder Site (referred to in this report as the "Clinch Bend Site") has been considered on several occasions as a 
potential location for a major manufacturing facility, including most recently the Mercedes Benz automotive plant. Given the limited resources of EDA and the intense competition for capital investment in the development of new industrial land, EDA requested an investigation of the suitability of the Clinch Bend site for development, identification of comparable, potentially competing properties, and an assessment of the need for additional industrial land in the region prior to further funding consideration.

The Oak Ridge Economic Adjustment Strategy includes the following four counties in the employment impact region based on the distribution of the work force impacts: Anderson, Knox, Loudon, and Roane Counties. Collectively, these counties account for more than 90 percent of all DOE employees. For the purposes of this study, Blount County has been added to the primary impact area because recent transportation improvements increase the integration of this area with Oak Ridge. The 25-mile radius study area also includes portions of four other counties: Campbell, Monroe, Morgan and Scott Counties.

The following figure shows the impact counties and 25-mile area surrounding the Clinch Bend site in relationship to the East Tennessee Development District.

Lockwood Greene, the nation's oldest and most experienced advisor to communities and companies on industrial economics issues, is working in partnership with The Oak Ridge Chamber of Commerce to review existing and potential industrial sites in the region and assess their characteristics and ability to meet the needs of likely industrial users.

This effort focuses initially on the Clinch Bend site. Other sites and developable tracts of land are identified with the assistance of communities in proximity to Oak Ridge, the State of Tennessee, and others, and compared with the projected site requirements for large industrial facilities. 


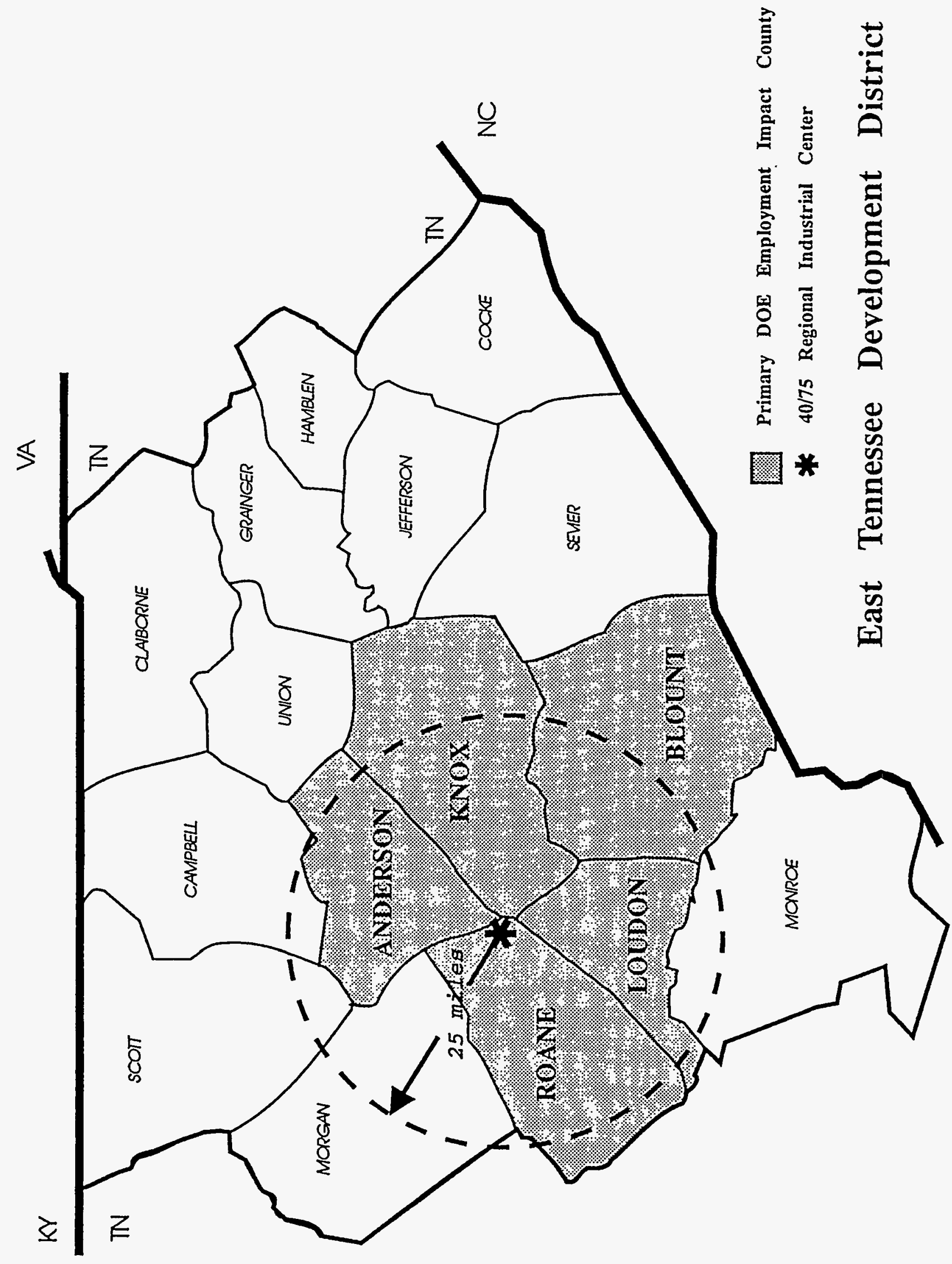




\section{Lockwood Greene Objectives}

There are several tasks in this program. The objectives for each task are summarized below:

\begin{tabular}{|c|c|}
\hline Task 1 & $\begin{array}{l}\text { Overview of existing industrial facilities in the Oak Ridge area } \\
\text { - inventory the developed sites and parks within } 25 \text { miles of Oak Ridge } \\
\text { - develop site data through interviews and published sources } \\
\text { - analyze trends in the demand for these industrial sites } \\
\text { Results: } \\
\text { Characterize the utilization of sites, the need for additional industrial sites and } \\
\text { projections of development trends }\end{array}$ \\
\hline Task 2 & $\begin{array}{l}\text { Assess the Clinch Bend Site relative to comparable sites in the area which } \\
\text { may serve as regional industrial sites } \\
\text { - develop criteria for determining site suitability and comparative site assessments } \\
\text { - select sites with potential to accommodate large industrial projects } \\
\text { - utilize the criteria to assess the strengths and weaknesses of River Site and the } \\
\text { comparable sites } \\
\text { Results: } \\
\text { Relative cost and effort required to develop sites and parks into regional industrial } \\
\text { assets, and assessment of their attraction to potential users }\end{array}$ \\
\hline Task 3 & $\begin{array}{l}\text { Identify other large tracts of land in the area which could be developed as } \\
\text { industrial sites in the near term } \\
\text { - work with nearby communities to identify large tracts with industrial site } \\
\text { potential } \\
\text { - develop criteria for comparing "greenfield" tracts } \\
\text { - assess tracts with respect to the criteria } \\
\text { - rank tracts according to suitability for industrial use } \\
\text { Results: } \\
\text { Determine if "greenfield" sites can meet the objectives of a regional industrial site, } \\
\text { relative cost and effort required to develop tracts into regional industrial assets, and } \\
\text { assess attraction to potential users }\end{array}$ \\
\hline Task 4 & $\begin{array}{l}\text { Assess community characteristics and barriers to economic development } \\
\text { - assess community assets and liabilities affecting overall cost, productivity, and } \\
\text { attractiveness for industrial projects that may utilize Oak Ridge sites } \\
\text { - generally contrast Oak Ridge with comparable communities } \\
\text { - focusing on success factors, identify areas where improvement is desirable and } \\
\text { possible } \\
\text { Results: } \\
\text { Recommend basic strategies for Oak Ridge to overcome major weaknesses, and } \\
\text { capitalize on strengths }\end{array}$ \\
\hline
\end{tabular}




\section{Conclusions and Recommendations}

The following are Lockwood Greene's key findings, and recommendations for action

\section{Overview of Existing Industrial Resources}

\section{Industrial Land Absorption Rates}

Lockwood Greene concludes that the high level of interest in the east Tennessee region demonstrated by major industrial corporations during the past several years will likely continue. This demand for industrial sites warrants the proactive identification and development of a regional industrial center within the Oak Ridge region.

At the most recent utilization rates, the total inventory of available land in Anderson County today could be absorbed in as little as 3.9 years.

A comprehensive assessment of the data on industrial sites within 25 miles of Oak Ridge developed during the period 1962-1995 indicates:

- Average annual absorption rate for the period is 128 acres per year.

- The range of absorption rates was from a low of 22 acres per year in Blount County to a high of 50 acres per year in Anderson County.

The overall supply of small to medium-sized industrial properties located in conventional industrial parks is generally adequate for meeting the immediately foreseeable needs on a regional scale.

- But available sites are not uniformly distributed and individual counties and communities, including Oak Ridge, are experiencing shortages in the local supply of available industrial land.

- There are few larger developed sites capable of accommodating major manufacturing projects or a complex of medium-sized manufacturing facilities.

\section{Existing Industrial Site Resources}

Existing commercial and industrial properties available in Oak Ridge are characterized by relatively small size and other limitations. These sites do not have sufficient capacity to support the type and level of industrial development needed to significantly mitigate the large employment impacts associated with the downsizing of the DOE operations. 
Two recognized existing industrial properties in the study area in addition to the Clinch Bend site initially were considered in this study:

Eastbridge Industrial Park in east Knox County Matlock Bend Industrial Site in Loudon County

up to 600 acres

$320-1,600+$ acres

\section{Greenfield Opportunities}

Two greenfield locations in addition to the Clinch Bend site are judged to offer potential opportunity for a regional industrial center, and are the subjects of the detailed comparisons in this report.

Lockwood Greene identified large tracts of land which have reasonable potential for development into a regional industrial site. These are not necessarily currently identified as industrial sites or parks, and may lack infrastructure necessary to support industrial facilities.

Lockwood Greene concluded that no greenfield site could be identified that met the initial minimum size criteria of 1,000 gross acres within the defined Oak Ridge study region. Consequently, Lockwood Greene conducted a second site screening effort lowering the minimum size criteria to 600 gross acres. Applying the lower size criteria, Lockwood Greene with the assistance of state and local economic development representatives identified several greenfield areas for assessment of their potential for development as a regional industrial center:

1. $900+$ acre site located in Roane County lying between the Clinch River and Interstate 40 about 1 mile west of the I-40/75 interchange, designated the Macedonia site, and,

2. $800+$ acre site located in Roane County west of Oak Ridge and north of the intersection of routes 58 and 95, designated the East Fork site.

\section{Site Assets and Liabilities}

The Clinch Bend site does not duplicate the resources presently available at an existing site. However, a comparison of Clinch Bend with greenfield alternatives results in another site alternative, the East Fork site, shown to be equal or superior to the Clinch Bend site on several key issues for the intended purposes.

In this section Lockwood Greene assumes the role of a corporate decision-maker, considers the available sites and greenfield tracts identified in this report, and assesses the strengths and weaknesses of the major site alternatives, including: 
- Specifying how sites fits decision criteria of industrial users that may be considering making a major investment in the community to implement a long-term strategic location decision.

- Determining the general range of investment and effort necessary to overcome liabilities, and produce a site that satisfies basic corporate expectations at the alternatives under consideration.

- Determining if other sites offer significant opportunity to meet these criteria, or can be modified to do so, in comparison with Clinch Bend.

Armed with this information, the Oak Ridge Chamber of Commerce is in a strong position to affect the direction and scope of state and federal programs to mitigate economic and community impacts due to downsizing, and to help structure regional cooperative efforts based on the facts.

\section{Clinch Bend Site}

The key site issues that favor investment by manufacturing companies at the Clinch Bend Site and which should be stressed in a marketing campaign are:

- Ready availability

- Relatively large size

- Proximity to rail and interstate highway system

- Potential for Barge access (although certainly not ideal)

- Access to markets

- Existing energy facilities

- Well-documented environmental issues

- Business/plant operating environment

Lockwood Greene has also identified several issues that can work against investment by manufacturing companies at the Clinch Bend site. These are:

- Site development cost factors

- Limitations on land area and site flexibility

- Perceived environmental risk

- Lack of visibility from interstate highway

- Commercial airline service 


\section{East Fork Site}

The key site issues that favor investment by manufacturing companies and the community at the East Fork Site, and in total support its dominant position relative to Clinch Bend are:

- Ready Availability

- Significantly greater usable land area

- Topography and land form allow more efficient and flexible land use

- Lower development cost factors; lower cost per acre of land to the user

- Improved accessibility, physical and visual; frontage on a major highway

- Rail access potential to nearly all of the developable tracts onsite

- Located in a growth corridor

- Utility extensions would support other development activity in the region

- Favorable operating environment, no competing or conflicting land uses

- Access to markets, labor force

Several issues that can work against investment by manufacturing companies at the East Fork site are:

- Shares with Clinch Bend a perception of environmental risk

- Undocumented site ecology and contamination issues

\section{Recommended Site Improvements and Costs}

Lockwood Greene concludes that the Clinch Bend site configuration and topography strongly suggest that the site is unlikely to be fully occupied by a single user, but that it is better suited for at least two or three sites serving different manufacturing operations.

Lockwood Greene further recommends that the best strategy for producing jobs in Anderson County and the Oak Ridge area is to preserve the option of using the site to attract a large user. This assures maximum flexibility in accommodating their unique needs regarding placement and configuration. This approach stands to yield the fastest utilization of the site and quickest return on the investment. If another option, in the form of a smaller project, appears and can be successfully marketed and there are no large projects on the horizon, a decision must then be made regarding the risk that this would pose for marketing the remainder of the site to a larger user.

Lockwood Greene's recommendation to invest in certain onsite improvements and enhancements to area infrastructure is made based on a comparison of: 
- The needs of manufacturers identified as likely to seriously consider the site

- Assessment of factors already adequately represented, either in-place or that are readily deliverable

- Estimated cost of the improvements necessary to overcome liabilities and increase the site's ability to satisfy projected users' needs

- Projected revenue stream to the community from land sales to site users

If the community decides to locate a smaller project on the site, then the direction of the investment and marketing strategy will likely shift to this type of user.

At this point it may be desirable to construct a speculative building to continue the momentum.

Investment in site infrastructure and improvements to maximize utilization and attractiveness for large users is estimated to exceed $\$ 34,000,000$. A direct link with Interstate Route 40 or bridge crossing of the Clinch River are not recommended, neither does this cost include landscaping or reclaiming the existing excavation on the site. Only about 600 acres are considered marketable to industrial users, consequently, the land cost to prospective corporate land purchasers would approach $\$ 57,000$ per acre. This is a major liability that risks the success of a regional industrial center at Clinch Bend.

The cause of the high development costs lies in part with the onsite topography and configuration. The recommended solution is to reduce the cost of site preparation and reduce the linear infrastructure. This can be achieved by a program which significantly reduces site grading programs, and focuses development exclusively on the main portion of the site for the time being, and avoiding "outlying areas" onsite. This approach depends heavily upon smaller users, requiring 20 to 30 acres of buildable land, with building requirements averaging approximately 250,000 square feet.

Under this alternative scenario the total investment cost of $\$ 16,027$ dictates a breakeven land selling price of $\$ 44,000$ per acre, a reduction from the base scenario of about 23\%. 


\section{Next Steps}

If Oak Ridge is going to successfully press its case for impact assistance the community will need to set a course of action and take deliberate steps to this end. Lockwood Greene recommends the following next steps:

\section{Site Acquisition and Investment}

Clinch Bend Site. If Oak Ridge decides to continue to actively pursue this site, it is necessary to increase its attractiveness, while preserving the option for a single large user or several medium size facilities. This necessitates developing a clear understanding of the conditions for making the site available from TVA, and laying out several development schemes that appear to be responsive to this and the NEPA environmental assessment requirements that TVA is bound to uphold. The following tasks should be undertaken:

- Obtain an initial statement of formal land transfer conditions and procedures from TVA.

- Establish an "asking price" for land.

- Clear site use and design alternatives through the EA process.

- Obtain required construction easements and rights-of-way from TVA and DOE to implement the minimum infrastructure improvements.

Initial capital investment should be held to the minimum necessary to achieve the objective of producing a marketable site. Infrastructure investments should be configured to maintain the maximum flexibility for future development. In other words, certain basic infrastructure should be put in-place, to the periphery of the developable site area. The minimum recommended requirements include:

- Upgrading water supply line to the site by the addition of pumps and installation of water storage capacity (standpipe) onsite.

- Upgrade waste water treatment capacity at the Bear Creek treatment facility, to 500,000 gallons per day, expandable to 1 million gallons per day. Construct sewer lines to the site.

- Construct a 4-lane access road from SR 58 to the northernmost developable portion of the site.

- Produce a display-quality design for the rail spur from DOE K-25, and a siding at the building site(s) reflected in the preliminary site layout scenarios (above). These will be important marketing tools. 
East Fork Site. This site deserves as much effort as can be mustered by the community of Oak Ridge and Eastern Tennessee. Initially it is necessary to develop preliminary data on a par with the Clinch Bend site. Site geology and soils, site ecology, and pollution require additional study. A preliminary site plan would be useful as it helps to establish the site's value in terms of its economic development potential; which in turn is relevant in the negotiations with DOE on the terms and conditions of title transfer and the selling price. Similarly, DOE's environmental assessment may uncover issues that affect site use/value.

Site flexibility and size are such that, unlike the Clinch Bend site, it is not necessary choose between large or small users. Utility extensions to the site boundary and a site access road from Route 95 can be undertaken in the near-term to market several tracts fronting Route 95 without too much concern for adversely impacting the potential to accommodate a large user on the upland portion of the site.

\section{Outreach and Cooperative Agreements}

Oak Ridge's reputation is national and international in scope, and by marshaling the resources present in the local business community it can produce a powerful voice for advancing the interests of business and residents alike. This requires a concerted effort to identify and plan for the effective utilization of these physical resources and management talent. The Chamber is moving in the right direction with the establishment of a Communication Task Force. Other steps to consider are:

- An Enterprise Committee to review business, community and government relations, and to assure business expansion/new business is not adversely affected by actions or omissions in this arena.

- An Entrepreneurs Network to provide the opportunity for linking local scientists, technical staff, and small businesses (including agribusiness), many of whom have relationships that span the country and the globe, in ways that foster home-grown businesses.

When other groups begin to see that the Chamber is serious about moving forward from this point, they will not risk being left behind.

Oak Ridge should take the initiative in forming a cooperative multi-jurisdictional relationship for the purpose of seeking broader support for and sharing of economic opportunity and costs associated with an enhanced Clinch Bend Site. The logical participants in addition to Oak Ridge include the communities that derive the greatest benefit, in relative terms, from a continued strong employment base at Oak Ridge: Anderson County, Roane County, Louden County and the State of Tennessee. 


\section{Target Industries}

Oak Ridge should begin planning now for the marketing of an enhanced Clinch Bend site or East Fork site. A good place to start is to convert the TVA target industry database, cited in this report, to industry targets. These would include the companies that can take advantage of the economic structure of the Oak Ridge area, and that can benefit from the Clinch Bend Site characteristics.

Following this the Chamber should prepare a brief marketing brochure for selected targeted industries. This communicates community understanding of industry needs, presents the case for industry to consider the benefits of capitalizing on Oak Ridge's strengths, and conveys a supportive environment for industrial decision makers. 


\section{Background}

In this section of the report, Lockwood Greene addresses the existing industrial development site resources and demand for industrial sites in Oak Ridge and the surrounding region. The existing industrial development resources are classified into two groups:

- Existing recognized industrial parks, and

- Available comparable large undeveloped tracts of land suitable for development (greenfield sites) in the region.

For the purposes of this analysis, the universe of industrial site resources is defined as all recognized industrial parks and identified greenfield sites within a twenty five mile radius of the Clinch Bend site and/or other sites located within the DOE employment impact counties.

The Oak Ridge Economic Adjustment Strategy includes the following four counties in the employment impact region based on the distribution of the work force impacts: Anderson, Knox, Loudon, and Roane Counties. Collectively, these counties account for more than 90 percent of all DOE employees. For the purposes of this study, Blount County has been added to the primary impact area because recent transportation improvements, including a new bridge over the Tennessee River, significantly increase the integration of this area with Oak Ridge. The 25-mile radius study area also includes portions of four other counties: Campbell, Monroe, Morgan and Scott Counties. All direct impact counties and those portions of other counties located within the 25-mile radius of the subject site are included in the KnoxvilleOak Ridge Trade Area and the East Tennessee Development District.

Lockwood Greene assessed the recognized industrial development site resources in the study based on information supplied by: the East Tennessee Development District's annual Industrial Land Inventory, interviews with leading economic development organizations in the region, the Tennessee Valley Authority, and the State of Tennessee's Department of Economic and Community Development. Information was obtained from interviews, surveys, and published and unpublished documentary sources; and the available industrial resource information was supplemented by site visits or field inspections for major identified developed and greenfield sites.

The existing parks and greenfield sites were screened on the basis of: the attractiveness for a major manufacturing firm, abilities to accommodate large manufacturing facilities, comparability in size and character to the Clinch Bend site, 
and potential for mitigating the effects of employment losses in the Oak Ridge area. The following sections present the results of this analysis, first for Oak Ridge industrial site resources and then as an overview of the regional resources.

\section{Oak Ridge Industrial Sites}

The Oak Ridge industrial site resources as identified by the Chamber and the East Tennessee Development District consist of Bethel Valley Industrial Park, Melton Hill Industrial Park, and Commerce Park. Lockwood Greene examined each of the identified existing industrial site resources in Oak Ridge. This examination revealed that Oak Ridge is faced with a critical shortage of vacant land and sites with the necessary services and facilities in place to serve the needs of new and expanding industry and, thus, to mitigate the economic impacts of the downsizing of the DOE operations in and around the community.

The industrial site shortage is particularly severe in the absence of sites suitable for the location of medium to large manufacturing plants. As of January 1995, the 118 acre Bethel Valley Industrial Park contains only 21 remaining net developable acres of land configured in small sites. Melton Hill Industrial Park is very small consisting of a total area of 17 acres with only about 15 developable acres remaining available. Commerce Park, the premier business park in Oak Ridge, is estimated to contain about 100-135 available vacant acres. Lockwood Greene examined Commerce Park and determined that, while the properties are highly attractive as a commercial office and business park and some sites are suitable for light industry, many available parcels are not contiguous and most are subject to moderate to severe physiographic constraints and strict development standards which generally limit the suitability and capacity to support conventional medium to large manufacturing industries.

Given the relatively small size and other limitations of the existing commercial and industrial properties available in Oak Ridge, Lockwood Greene concludes that these sites do not have sufficient capacity to support the type and level of industrial development needed to significantly mitigate the large employment impacts associated with the down-sizing of the DOE operations. 


\section{Regional Industrial Parks and Sites}

The draft Industrial Land Inventory prepared in January 1995 by the East Tennessee Development District identifies a total of 32 recognized "industrial" properties with "available" sites located within the study area. Of the total identified sites, 31 properties are located in an area within a 25-mile radius of the Clinch Bend site including three sites (two in Monroe County and one in Morgan County) located outside the boundaries of the primary impact counties. One industrial property, Eastbridge Industrial Park, is located outside the 25-mile radius but within the impact area in Knox County.

The following figure illustrates the locational distribution of the industrial properties initially considered by Lockwood Greene for this analysis.

The information on the included sites (provided by the Development District) was verified and updated through personal or telephone interviews with the various economic development organizations responsible for marketing these properties in each county. It should be noted that the definition of "industrial land" used by the Development District is broad and includes some properties not oriented toward manufacturing which may be better characterized as business, commercial, or distribution sites and parks. Regardless of this limitation, all identified "industrial land" has been considered in this analysis and the existing industrial properties have been characterized by Lockwood Greene on the basis of available acreage, utilities, transportation access, and the year sites were first actively marketed, as shown in the following table.

Examination of the data on the 32 existing recognized industrial parks and sites with available land shows the following:

- Historically these areas totaled 7,225 acres of land. Of the total, 4,166 acres or about 58 percent has been developed or committed to date.

- Of the remaining 3,059 acres of vacant and developable land, about 572 acres are located in parks or areas with patterns of development not oriented toward manufacturing industries or, though vacant, are otherwise limited by factors such as zoning restrictions, development standards, or the presence of existing purchase options.

The primary objective of this study is to identify major sites with the potential to support the creation of significant numbers of manufacturing jobs to offset the regional economic impacts of downsizing the Oak Ridge DOE operations. Thus, Lockwood Greene examined the remaining sites totaling 2,487 acres to determine the capability of accommodating at least one large manufacturing industry in 


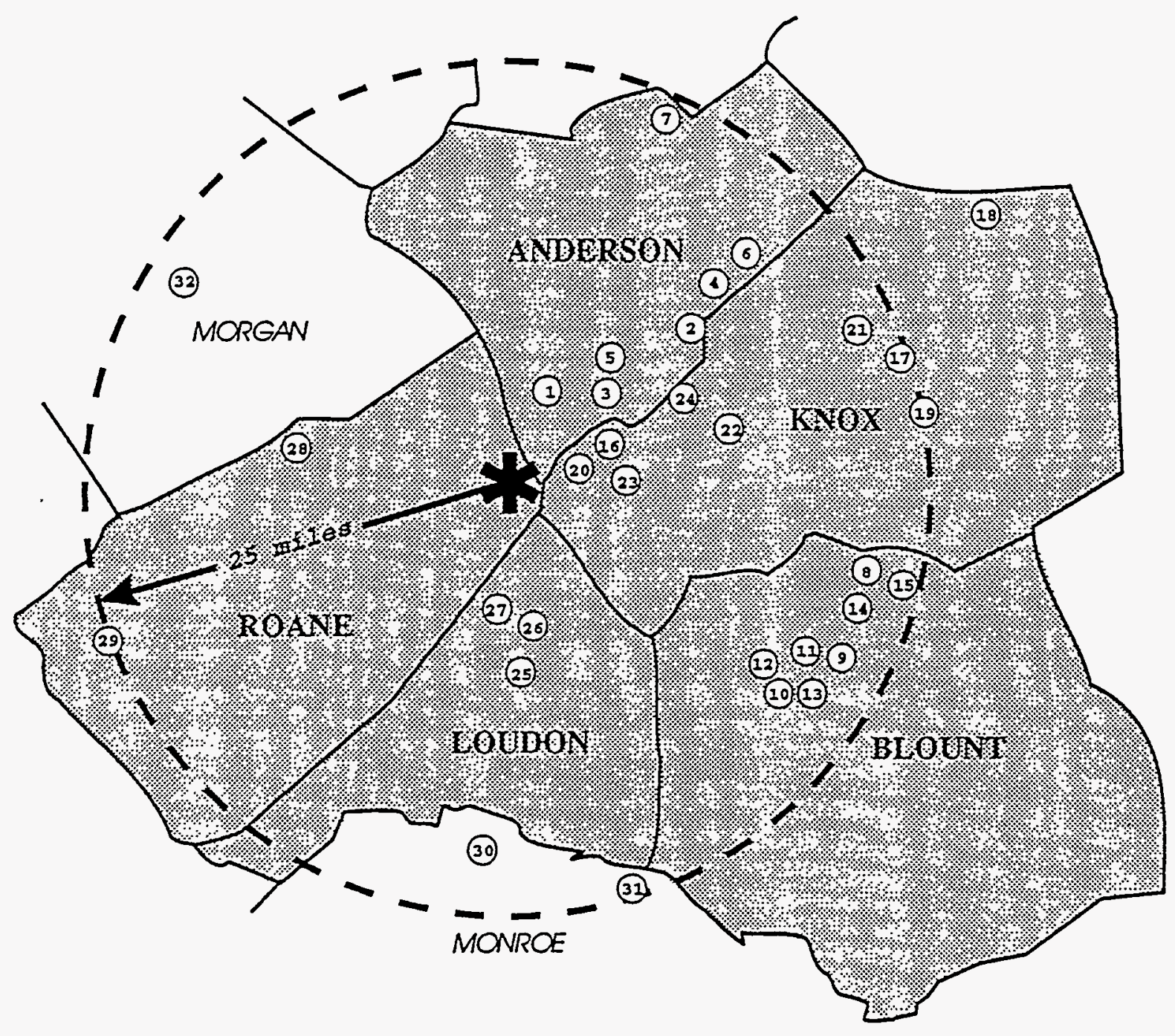

\% Primary DOE Employment Impact County

40/75 Regional Industrial Center

(30) Existing Industrial Parks

\section{Existing Industrial Parks and Sites in the Oak Ridge Region}


Existing Recognized Industrial Parks and Sites in the Oak Ridge Region Overview

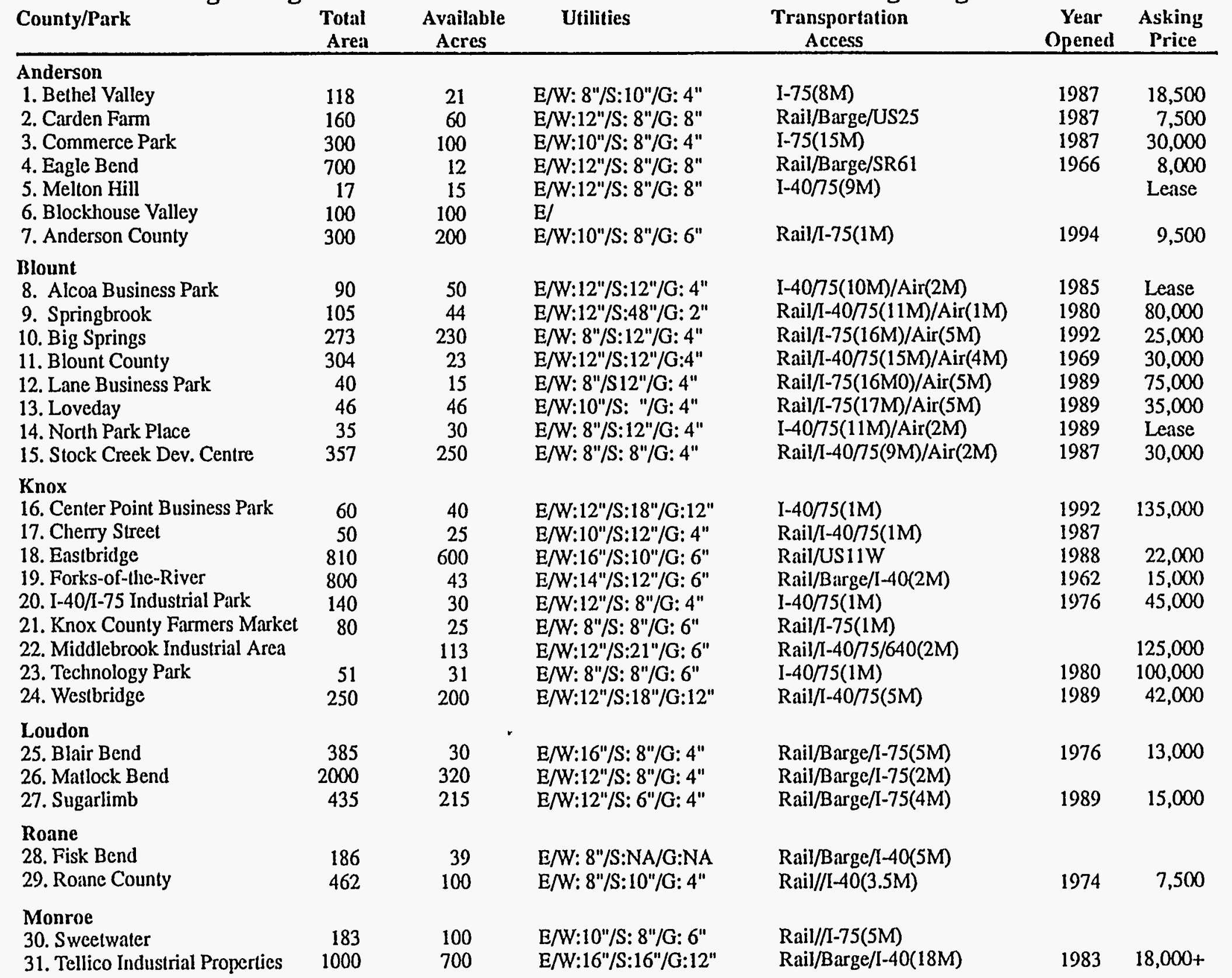

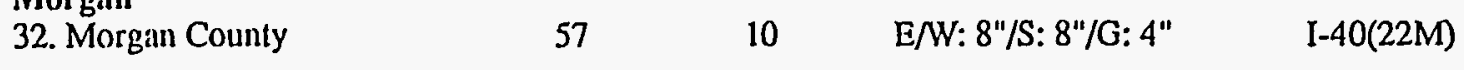


conjunction with one or more medium--sized ancillary support facilities, or a major manufacturing industrial complex including at least three substantial medium-sized manufacturing plants. Based on Lockwood Greene's experience in siting large industrial facilities and major manufacturing complexes, a minimum of 100 to 150 net developable acres in one contiguous site and an additional 100+ net developable acres in one or more nearby large tracts is required to meet the minimum criteria for major industrial projects. In addition to this minimum criteria, it is usually highly desirable to have additional undeveloped acreage available to provide an adequate buffer zone. Thus, it is common to have major manufacturing industrial prospects seeking sites containing a minimum of 150 to 300 net developable acres and 250 to $1000+$ gross acres of land.

Although seven industrial properties contain net developable areas in excess of 200 acres, most were broken into several smaller sites or otherwise had development patterns or physiographic constraints which prevent assemblage of a site suitable for a single large manufacturing industry or industrial complex. Based on the above criteria for the development of major industrial projects, only three recognized existing industrial properties in the study area in addition to the Clinch Bend site were considered further:

\section{Site \#}

18. Eastbridge Industrial Park in east Knox County

26. Matlock Bend Industrial Site in Loudon County

31. Tellico Industrial Properties in Monroe County
Area in Acres

600 (est.)

$320-1,600$

$700+$

\section{Eastbridge Industrial Park}

This site is more than 25 miles from the Clench Bend Site, but it is in an impact county (Knox) and contains undeveloped land. Based on contacts with the community for the purpose of identifying a large tract here, we conclude that this is not presently available for the targeted purpose.

\section{Matlock Bend Industrial Site}

This publicly owned industrial park consists of 2,000 acres in Loudon County We investigated the possibilities at this site, but as currently configured it only offers 320 undeveloped acres, well below the minimum for consideration herein.

\section{Tellico Industrial Properties}

The locational characteristics of this site are unlikely to meet basic economic and employment objectives guiding this study. Briefly, the following factors led to this decision:

- The Tellico site is located in Monroe County, outside the designated DOE primary employment impact area and situated on the outermost edge of the 25- 
mile radius from Oak Ridge and the Clinch Bend Site. It is even more remote from the communities where most of the DOE work force currently reside. In addition to distance, it is also relatively inaccessible to this population and would require a lengthy, circuitous commute over two-lane routes.

- The closest access to interstate Route 75 is 14 miles from the site at SR 72 near Loudon, Tennessee. The only other alternative access route is via US Highway 411 , a two-lane route with substandard right-of-way. For a regional industrial center, access to a controlled access highway of interstate quality within 10 miles is considered a key locational criteria for major manufacturers.

In summary, the site is unlikely to provide the level of access and job opportunity needed to mitigate the loss of DOE employment at Oak Ridge or be particularly attractive to a variety of corporate decision-makers seeking to site major facilities.

\section{Greenfield Opportunities}

Lockwood Greene identified large tracts of land which have reasonable potential for development into a regional industrial site. These are not necessarily currently identified as industrial sites or parks, and may lack infrastructure necessary industrial facilities, but are of such size and have other assets that they may have potential as regional industrial centers.

The preliminary screening for potential suitable greenfield sites used only two criteria:

1. Location: within the 25 -mile radius of the Clinch Bend site, and/or within a designated DOE impact county; and

2. Size: A minimum gross area of 1,000 contiguous acres capable of being assembled as one major manufacturing industrial site.

Using these criteria, Lockwood Greene examined regional maps, aerial photos, and other available data sources to identify potential candidate sites in the region. Data and comments were also solicited from leading economic development organizations and other knowledgeable persons in the region. Potential candidate site areas throughout the region were also reviewed with the Tennessee Department of Economic and Community Development and the Tennessee Valley Authority. It should be noted that, because these potential industrial site areas have had little previous consideration as industrial sites, only limited data was available on industrial development potential. 
Lockwood Greene's investigation resulted in the conclusion that no previously unidentified greenfield site could be identified that met the minimum size criteria of 1,000 gross acres within the defined Oak Ridge study region.

Consequently, Lockwood Greene conducted a second site screening effort lowering the minimum size criteria to 600 gross acres. Although less than desirable, Lockwood Greene determined 600 gross acres to be the minimum acceptable site size for a greenfield site capable of accommodating a large manufacturing facility. The primary concern with the lowered size criteria is that, although most industries require a smaller net area of developable land, the physiographic limitations in East Tennessee including floodplains and severe topographic constraints often entail the acquisition of substantially larger gross amounts of land in order to obtain the minimum amount of developable land and additional buffer area required to meet the needs of major industrial prospects.

Applying the lower size criteria, Lockwood Greene with the assistance of state and local economic development representatives identified two greenfield sites as candidates for assessment of the potential for development as a regional industrial center:

1. A 900 acre site located in Roane County lying between the Clinch River and Interstate 40 about 1 mile west of the I-40/75 interchange, designated the "Macedonia" site.

2. A $800+$ acre site located in Roane County west of Oak Ridge and north of the intersection of routes 58 and 95 , bordering the eastern limit of the DOE K-25 area, and designated as the "East Fork" site.

A $600+/-$ acre potential site located in Blount County north of the metro airport in the vicinity of the Louisville Community and Topside Road was considered but community planning and interest in this area has not progressed to the degree that it is considered a viable candidate. 


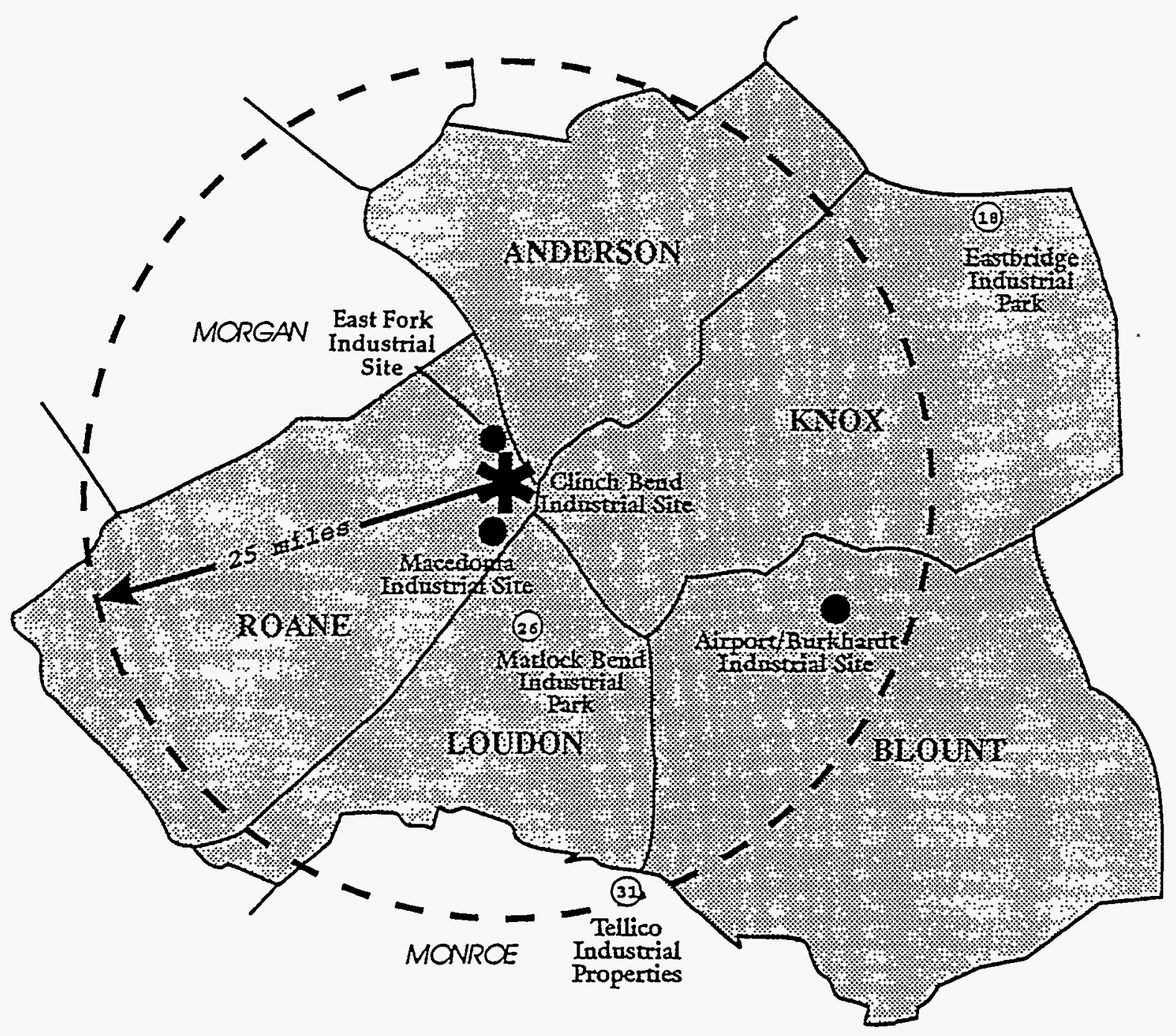

1 Primary DOE Employment Impact County

* 40/75 Regional Industrial Center

(30) Selected Existing Industrial Parks or Sites

Proposed "Greenfield" Industrial Sites

\section{Candidate Regional Industrial Center Sites in the Oak Ridge Region}




\section{Industrial Land Absorption Rates}

Lockwood Greene examined the demand for industrial land in the Oak Ridge region. Detailed data concerning the demand for individual sites by year was not available; however, information was available for the following:

- Year in which each existing industrial area was placed on the market.

- Total area in acres for each industrial park or site.

- Estimated remaining net developable acres in each park or site.

Based on the available data, average absorption rates were estimated for each known time period as land entered the market. Industrial land absorption rates were calculated for each county in the study area and the Oak Ridge region as a whole.

It should be noted that the data analyzed was for those industrial areas with available land as of January 1995. Information provided by the East Tennessee Development District indicated that, during the period covered by this study (19621995), other industrial land was placed on the market in the region and subsequently fully developed. These previously fully developed industrial parks and sites are omitted from the current study because data on size, year entering the market, and year fully developed was not available. Therefore, the following estimates of average industrial land absorption rates may be considered conservative.

It should also be noted that average rates are crude measures at best because the consumption of industrial sites is lumpy. In any given year industrial land absorption may vary greatly, no sites may be developed, several sites developed, a very large site developed, or a combination of large and small sites may be developed. Averages tend to obscure these variations; however, these averages provide at least a general indication of trends in the relative demand for industrial land across the region for various time periods during the past 33 years.

The following table summarizes the available data on industrial land absorption for the Oak Ridge Region by county and time period. It shows that during the period 1962-1995:

- A total of 7,225 industrial acres were placed on the regional market.

- Approximately 58 percent or 4,166 acres are currently developed.

- The average absorption rate for the region as a whole was 126 acres per year.

- Across all time periods for the region, the median absorption rate by county was 23 acres per year. 
Industrial Land Absorption Rates by County and Oak Ridge Region

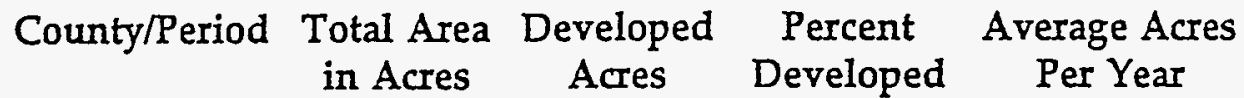

\begin{tabular}{|c|c|c|c|c|}
\hline \multicolumn{5}{|c|}{ Anderson Co } \\
\hline 1966-1995 & 1578 & 1185 & 75 & 41 \\
\hline 1987-1995 & 578 & 397 & 69 & 50 \\
\hline $1994-1995$ & 300 & 100 & 33 & 100 \\
\hline \multicolumn{5}{|l|}{ Blount Co } \\
\hline 1969-1995 & 1204 & 562 & 47 & 22 \\
\hline $1980-1995$ & 900 & 281 & 31 & 19 \\
\hline 1985-1995 & 795 & 220 & 28 & 22 \\
\hline $1987-1995$ & 705 & 180 & 26 & 23 \\
\hline $1989-1995$ & 348 & 73 & 21 & 6 \\
\hline $1992-1995$ & 273 & 43 & 16 & 14 \\
\hline \multicolumn{5}{|l|}{ Knox Co } \\
\hline $1962-1995$ & 2161 & 1182 & 55 & 36 \\
\hline $1976-1995$ & 1361 & 425 & 31 & 22 \\
\hline $1980-1995$ & 1221 & 315 & 26 & 21 \\
\hline $1987-1995$ & 1170 & 295 & 25 & 37 \\
\hline $1988-1995$ & 1120 & 270 & 24 & 39 \\
\hline $1989-1995$ & 310 & 70 & 23 & 12 \\
\hline $1992-1995$ & 60 & 20 & 33 & 7 \\
\hline \multicolumn{5}{|l|}{ Loudon Co } \\
\hline 1976-1995 & 820 & 575 & 70 & 30 \\
\hline $1989-1995$ & 435 & 220 & 51 & 37 \\
\hline \multicolumn{5}{|l|}{ Roane Co } \\
\hline $1974-1995$ & 462 & 362 & 78 & 17 \\
\hline \multicolumn{5}{|l|}{ Monroe Co } \\
\hline $1983-1995$ & 1000 & 300 & 30 & 25 \\
\hline \multicolumn{5}{|l|}{ Region } \\
\hline $1962-1995$ & 7225 & 4166 & 58 & 126 \\
\hline $1969-1995$ & 6121 & 3024 & 49 & 116 \\
\hline $1974-1995$ & 5659 & 2662 & 47 & 127 \\
\hline $1980-1995$ & 4434 & 1613 & 36 & 128 \\
\hline $1985-1995$ & 3278 & 1232 & 38 & 123 \\
\hline $1989-1995$ & 1393 & 463 & 33 & 77 \\
\hline
\end{tabular}


In order to compare county levels of land absorption on relatively similar basis, Lockwood Greene selected the period 1985-1995. The demand for industrial land is affected directly by variations in the business cycle. This period is selected because it is sufficiently long to cover at least one expansion and recession period. During the 1985-1995 period:

- The region added a total of 3,278 acres of industrial land.

- As of January 1995, 36 percent or 1,232 acres were developed.

- Average annual absorption rate for the period is 128 acres per year.

- The range of absorption rates was from a low of 22 acres per year in Blount County to a high of 50 acres per year in Anderson County.

Based on the range of average absorption rates, the available data indicates that the projected average life of the remaining industrial land by county ranges from an estimated low of 6 years in Roane County to a high of 29 years in Blount County. The following table illustrates the estimated remaining life of the available industrial land inventory by county based on the historical average absorption rates.

\section{Projected Industrial Land Absorption by County}

\begin{tabular}{lccccc}
\multicolumn{1}{c}{ County } & Total Acres & $\begin{array}{c}\text { Developed } \\
\text { Acres }\end{array}$ & Available & $\begin{array}{c}\text { Absorption } \\
\text { Rate/year }\end{array}$ & $\begin{array}{c}\text { Estimated } \\
\text { Life (yr.) }\end{array}$ \\
Anderson & 1,578 & 1,185 & 393 & $40-50$ & $8-10$ \\
Blount & 1,204 & 562 & 642 & 22 & 29 \\
Knox & 2,161 & 1,182 & 979 & 37 & 26 \\
Loudon & 820 & 575 & 245 & $30-37$ & $7-8$ \\
Roane & 462 & 362 & 100 & 17 & 6 \\
Monroe & 1,000 & 300 & 700 & 25 & 28
\end{tabular}

As previously discussed, the above averages are crude measures of demand. For example, in 1994, Anderson County added 300 acres of industrial land in the Anderson County Industrial Park. Of this amount, about 100 acres (33 percent) were developed within the first year. At this rate, the total inventory of available land in Anderson County would be absorbed in as little as 3.9 years.

Furthermore, the available data do not address the issue of the potential industrial locations which were lost due to the absence of a suitable site. The vast majority of available sites in the region are small, ranging from 2 to 25 acres. These sites, which are included in the existing inventory, are not suitable for manufacturing industries of any magnitude. The Tennessee Department of Economic and Community Development indicates that a minimum of one major industrial project considers locating in the state each year. Recent locations within the Oak Ridge region such as 
the Nippondenso and Honda facilities also suggest the area is attractive to owners of medium to large-sized manufacturing plants, as does the consideration of the Clinch Bend site for the Mercedes Benz automotive manufacturing and assembly complex.

Based upon the information provided by the State, TVA, and the other leading economic development organizations in the region and the above analysis of the industrial land inventory and historical absorption rates, Lockwood Greene concludes:

- The overall supply of small to medium-sized industrial properties located in conventional industrial parks is generally adequate for meeting the immediately foreseeable needs on a regional scale.

- Available sites are not uniformly distributed and individual counties and communities, including Oak Ridge, are experiencing shortages in the local supply of available industrial land.

- There are few larger developed sites capable of accommodating major manufacturing projects or a complex of medium-sized manufacturing facilities.

- Given the interest shown by major industrial prospects in the east Tennessee region during the past several years, sufficient manufacturing industrial demand exists to warrant the identification and development of a regional industrial center within the Oak Ridge region. 


\section{Site Assets and Liabilities}

\section{Objectives}

The Clinch Bend site, other developed sites, and greenfield tracts in the Oak Ridge area contain within them the seed of industrial development opportunity. Sites offering the best opportunity are those that would be perceived by corporate decision-makers to satisfy key site criteria, and which can be made available to them at a reasonable cost.

In this section Lockwood Greene assumes the role of a corporate decision-maker, considers the available sites and greenfield tracts identified in the previous sections of this report, and assesses the strengths and weaknesses of the major site alternatives.

Armed with this information, the Oak Ridge Chamber of Commerce and other communities in the region will be in a much stronger position when deciding upon locational alternatives that make sense for a regional industrial park. Specifically, it will enable Oak Ridge to achieve several objectives:

- Identify how the Clinch Bend Site fits decision criteria of industrial users that may be considering making a major investment in the community to implement a long-term strategic location decision.

- Determines the general range of investment and effort necessary to overcome liabilities, and produce a site that satisfies basic corporate expectations.

- Determines if other sites offer significant opportunity to meet these criteria, or can be modified to do so, in comparison with Clinch Bend. 


\section{Perspectives on the Important Site Issues}

From the public economic development perspective a site should be selected as the preferred focus of community development efforts for sound cost and procedural reasons. In general, properties targeted for conversion to industrial sites to meet future needs will likely be a compromise between:

- Assets which the community can develop and offer to industry in a reasonable time frame at a reasonable cost, and

- The community's understanding of the manufacturing assets being sought by industry.

Clearly, the understanding of industry requirements is the key, as it determines the community effort likely to be required. At the basic level, from the perspective of a company about to invest large sums of capital, a desirable site is one which:

- Exhibits the traits that ensure it is a good place to do business now, that is, it is compatible with contemporary business practices.

- Positions the company to meet the competition anticipated in future years.

- Satisfies the decision-maker's need to minimize personal risk and demonstrate to the owners that management has effective control over project costs.

Lockwood Greene's experience working with communities and corporate decisionmakers suggests there is common ground upon which Oak Ridge can base preliminary decisions regarding a desirable site. These broadly guide Lockwood Greene's assessments on the following pages:

- Sites should be sufficiently large to accommodate several uses, for example:

- Large manufacturer with several distinct operations conducted in close proximity, e.g. an electric power cable manufacturing plant, with nearby insulation compounding plant, rail freight operations and storage yard, and distribution facility.

- Operations requiring collocation of vendors or suppliers, using just-intime material flow. 
- Site infrastructure is assessed in the context of other actual manufacturing projects:

- Plants located by Lockwood Greene professionals in recent years

- Projects which are currently in a site selection mode.

Very large "mega" projects should not be used as a yardstick for planning a regional industrial site. This is not a productive approach, given the relatively small number of such projects and the large number of communities competing for them when they do surface.

- In Lockwood Greene's experience it is neither possible nor desirable to predict the final stipulated site requirements or negotiating posture of very large industrial projects.

- Companies will expect or demand additional participation by state and local authorities in project financing and in-kind assistance, regardless of how well the site fits their initial criteria, or the magnitude of community investment incurred prior to the company's interest in the community. Focusing on these issues ahead of time risks exposing Oak Ridge to even greater corporate demands and expectations in due course.

- The time to consider this type of site investment is after the basic project requirements have been met, and the company begins negotiating at a few selected communities. 


\section{The Corporate Location Decision Process}

A corporate decision to locate a major manufacturing plant in the Oak Ridge area will be undertaken as part of a larger review of long-term corporate strategic objectives.

- The decision will be reached after considering the implications of carefully selected scenarios, including different operating and location alternatives.

- For Oak Ridge to be considered, the community first must satisfy initial criteria that reflect the company's general business objectives.

- Very probably one of the basic requirements at this stage will be that communities contain at least one site which on the basis of cursory review, e.g. written information, appears to offer the company an opportunity to meet its objectives. Only after passing this test will detailed investigations be undertaken in the Oak Ridge area.

Assuming that Oak Ridge meets this test, a detailed set of plant/site operating specifications will be developed, and based on these a statement of detailed site selection criteria will be developed and applied to asses the "goodness of fit" at Oak Ridge and at the other communities being considered for the project..

It is these criteria, used to guide a typical industrial site selection team, which should guide The Chamber's decisions regarding the sites which the community may want to develop. Several key points to keep in mind regarding these criteria are:

- Criteria are developed specifically for each project decision by each company, to reflect unique concerns which arise from:

- The success factors that have propelled the business and which the company seeks to capitalize upon in locating a new facility.

- The company's history, the problems and successes it has experienced in other operating environments.

- Site assets that the company believes can be achieved at less cost or inconvenience by negotiating at the present location to remain/expand inplace, or by locating at sites in other communities.

- In Lockwood Greene's experience, not every industrial facility location decision is based on significant existing infrastructure or other site attributes, but, in general, a minimum level necessary to meet the most likely set of location criteria is desired.

Criteria evolve as the project progresses, becoming more complex and more demanding the longer a site selection project continues. 


\section{Corporate Site Selection Criteria}

In assessing the Clinch Bend site and alternatives Lockwood Greene has applied the following broad site selection criteria.

\begin{tabular}{|c|c|}
\hline \%ै। Issue & 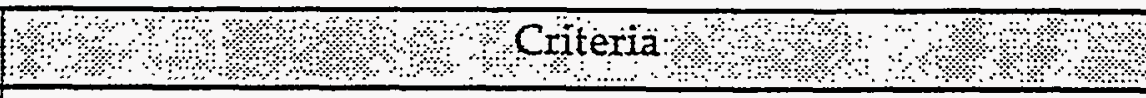 \\
\hline Size, configuration, image & $\begin{array}{l}\text { Minimum } 600 \text { - } 800 \text { acres, buffered from nearby land uses, not } \\
\text { unattractive in comparison with other locations or facilities } \\
\text { operated by area employers. Interstate visibility is a plus. }\end{array}$ \\
\hline Topography, grading & $\begin{array}{l}\text { Site should accommodate multiple users. Must be able to } \\
\text { develop at least three level areas of approximately } 130 \text { to } 150 \\
\text { acres; } 70 \text { acres; and } 30 \text { acres. }\end{array}$ \\
\hline Transportation & $\begin{array}{l}\text { Truck access from an interstate route within } 10 \text { miles. In } \\
\text { urbanized areas, 4-lane access is preferred. }\end{array}$ \\
\hline & $\begin{array}{l}\text { Rail line should be at the site boundary, or at a minimum, } \\
\text { engineered (with costs) to provide a spur at the plant site. }\end{array}$ \\
\hline Energy & $\begin{array}{l}\text { Potential for looped electric power (dual substation) is preferred; } \\
\text { two transformers (single substation) is acceptable. }\end{array}$ \\
\hline & Natural gas service at $150-300$ psi to site boundary. \\
\hline Water, sewer & $\begin{array}{l}\text { Water: } 500,000 \text { gallons per day fresh water, expandable to at least } \\
1 \mathrm{mgd} \text {. }\end{array}$ \\
\hline & $\begin{array}{l}\text { Sewer: } 500,000 \text { gpd existing capacity, expandable to at least } 1 \\
\text { mgd. }\end{array}$ \\
\hline $\begin{array}{l}\text { Environmental, sensitive } \\
\text { lands }\end{array}$ & $\begin{array}{l}\text { Plant operating parameters should not be adversely impacted by } \\
\text { undesirable emissions from offsite activities, and worker health \& } \\
\text { welfare must be protected. }\end{array}$ \\
\hline & $\begin{array}{l}\text { No onsite ecological or cultural resources that significantly limit } \\
\text { site uses or require continuing regulatory/reporting involvement. }\end{array}$ \\
\hline $\begin{array}{l}\text { Site acquisition or } \\
\text { development constraints }\end{array}$ & $\begin{array}{l}\text { Prefer one or two landowners, without known property transfer } \\
\text { objections, or legal impediments that adversely affect transfer. }\end{array}$ \\
\hline Land cost & Reasonable and competitive with other sites. \\
\hline
\end{tabular}




\section{Assessment of Oak Ridge Area Industrial Sites}

Lockwood Greene's review of currently available industrial sites and land that might be made available and supported by communities in the region for conversion to industrial sites are documented in Section 2 of this report. Based on this review two greenfield sites stood out as worthy of additional consideration.

\section{Macedonia}

This is a mostly undeveloped tract of land in Roane County, Located directly south of the Clinch Bend site and across the Clinch River. This site was also considered for the Mercedes project. It is nearly vacant, except for light recreation and residential use near the river. Interstate 40 abuts the site on the south.

\section{East Fork}

Owned by the U.S. Department of Energy, this is an undeveloped tract, located two miles northeast of the Clinch Bend site. It is virtually dissected by the East Fork Poplar Creek, which flows east to west through the site. A severe infestation of southern pine borer has decimated the timber here, and much of the area has been logged in an attempt to control its spread.

Lockwood Greene has examined the available information on these properties and the Clinch Bend site, and developed additional information as necessary to conduct an assessment of the overall assets and liabilities. This is summarized in the matrix on the following pages. 


\section{Comparative Site Assessment \\ Acreage, Configuration and Image}

\begin{tabular}{|c|c|c|}
\hline & Acreage \& Configuration & Image \\
\hline $\begin{array}{c}\text { Clinch Bend } \\
\text { 1,200 Ac. }\end{array}$ & $\begin{array}{l}\text { - } 400 \text { industrial acres are contained at this location. } \\
\text { - Approximately three level/graded sites ( } 135 \text { acres, } 70 \text { acres } \\
\text { and } 30 \text { acres) are possible } \\
\text { - Tracts are not contiguous, and are at different elevations. } \\
\text { - Secondary sites are irregular in shape, and topography limits } \\
\text { flexibility, due to high cost of additional grading, and the } \\
\text { environmental sensitivity of ridges and slopes. } \\
\text { - Additional sites are not possible at this location }\end{array}$ & $\begin{array}{l}\text { - It is possible to utilize this natural river setting to provide } \\
\text { aesthetic and recreation amenities at little cost. } \\
\text { Corporate industrial users would find the primary site and } \\
\text { its environs to be a very attractive location, one that works } \\
\text { for the recruitment and retention of staff. } \\
\text { - If the earth pile from reactor excavation remains in-place, } \\
\text { special landscape treatment will be required, at additional } \\
\text { cost, to minimize aesthetic impacts. }\end{array}$ \\
\hline $\begin{array}{l}\text { Macedonia } \\
\text { 1,000 Ac. }\end{array}$ & $\begin{array}{l}\text { - } 900+\text { industrial acres possible at this location. } \\
\text { - Approximately six level graded sites (150,70,36, 26, 15, and } \\
13 \text { acres) are possible. } \\
\text { - Developable tracts are not contiguous, and at different } \\
\text { elevations. } \\
\text { - Secondary sites are irregular in shape. }\end{array}$ & $\begin{array}{l}\text { The smaller sites (e.g. } 30 \text { Ac.) with river views are } \\
\text { attractive, and the area generally would be preferred for its } \\
\text { natural setting. } \\
\text { - However, low sites at river may be perceived as a flood risk } \\
\text { by industrial users. }\end{array}$ \\
\hline $\begin{array}{l}\text { East Fork } \\
800 \mathrm{Ac} .\end{array}$ & $\begin{array}{l}\text { - } 715+\text { industrial acres at this location. Slope is generally } 5 \% \text { to } \\
10 \% \text {. } \\
\text { - Approximately four graded sites }(230+, 60,55 \text {, and } 20 \text { acres }) \\
\text { are easily possible; other less accessible tracts also possible. } \\
\text { - Tracts are separated by stream and/or } 100 \text {-year floodway }\end{array}$ & $\begin{array}{l}\text { - East Fork is a natural buffer between sites, and offers } \\
\text { opportunity for attractive landscape treatment. } \\
\text { - Pine (borer) clearing program creates views/vistas. } \\
\text { - Vistas are not obstructed by nearby development. }\end{array}$ \\
\hline
\end{tabular}




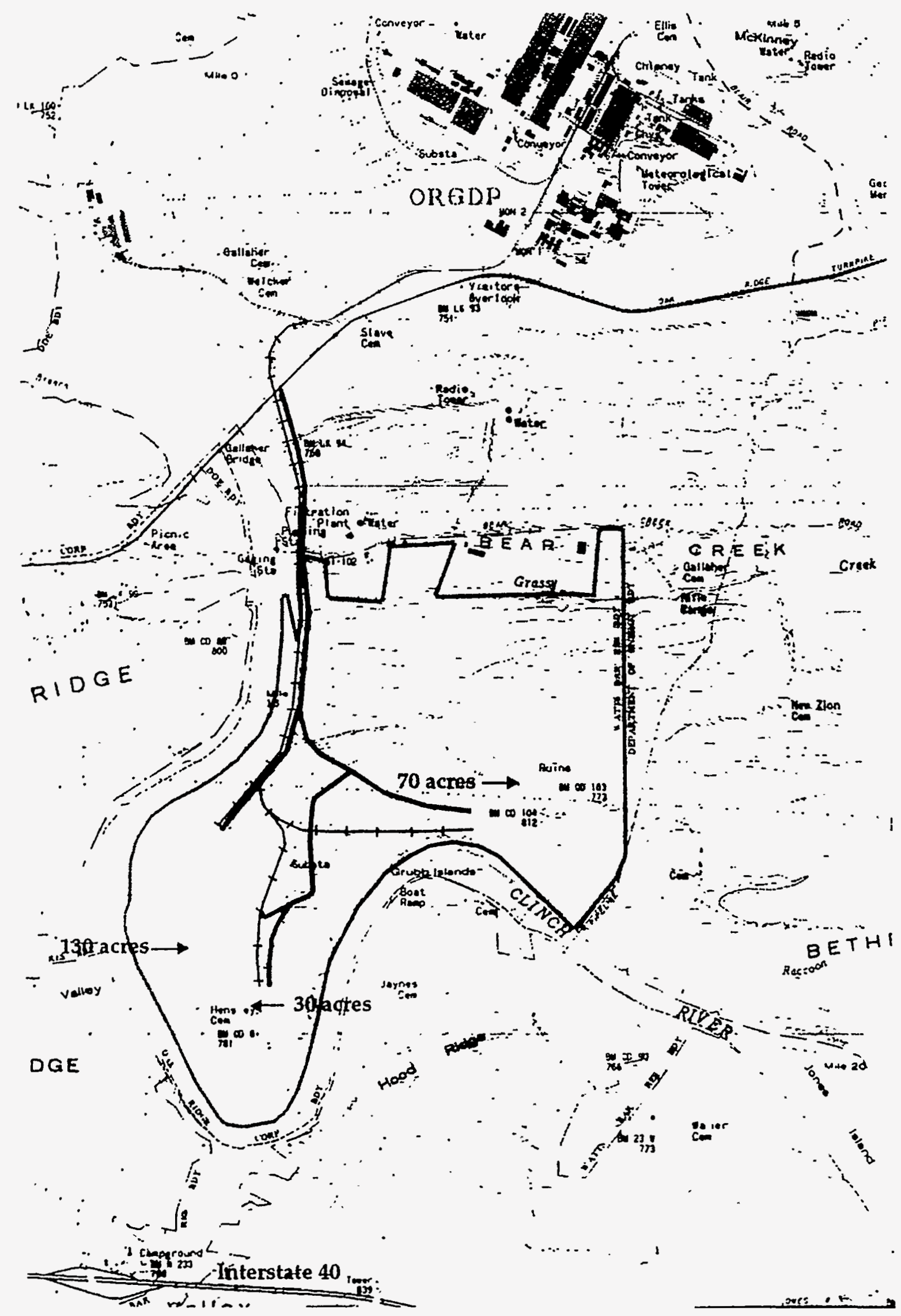

Clinch Bend Site

Location of Proposed Grading, Roads, and Rail Access 


\section{Comparative Site Assessment \\ Site Grading \& Flooding}

\begin{tabular}{|c|c|c|}
\hline & Grading & Flooding \\
\hline Clinch Bend & $\begin{array}{l}\text { Major earth work is required to fill existing excavation } \\
\text { onsite. } \\
\text { Rough grading costs to prepare a } 135 \text { Ac pad at elevation } 780 \\
\text { ft for use as the primary site is estimated @ } \$ 16,300,000 \text {. } \\
\text { - Additional grading to level other sites: } 70 \text { Ac @ } \$ 5,880,000 \text {; } \\
\text { and } 30 \text { Ac @ } \$ 2,700,000 \text {. }\end{array}$ & $\begin{array}{l}\text { - Clinch River } 500 \text {-year flood is at elevation } 760 \mathrm{ft} \text { at site. } \\
\text { Probable maximum flood with wave run-up at site is } 780 \mathrm{ft} \text {. } \\
\text { Postulated seismic failure of upstream dams produce flood } \\
\text { levels of } 796-805 \mathrm{ft} . \text {, and other scenarios produce flood } \\
\text { levels up to } 818 \mathrm{ft} \text {. } \\
\text { - Primary site is above probable worst case flood, with dam } \\
\text { failure. } \\
\text { - Other sites (at estimated ele. } 780 \mathrm{ft} \text { ) are susceptible to } \\
\text { flooding from dam failure }\end{array}$ \\
\hline Macedonia & $\begin{array}{l}\text { - Primary graded site of } 160+\text { acres is possible. } \\
\text { - Cost of rough grading } 135 \text { acres (ele } 793 \mathrm{ft} \text { ) is estimated @ } \\
\$ 10,260,000 \text {. } \\
\text { Additional grading is required to level other sites: } 70 \mathrm{Ac} @ \\
\$ 7,350,000 \text {, and } 30 \mathrm{Ac} @ \$ 2,730,000 \text {. }\end{array}$ & $\begin{array}{l}\text { - Clinch River Flooding is same as above. } \\
\text { Primary site and } 70 \text { Ac site are above probable maximum } \\
\text { flood but subject to flooding from dam failure. } \\
\text { The } 30 \text { Ac site is above } 500 \text { year flood, but at ele } 760-770 \\
\text { ft, is subject to probable maximum flood and all dam } \\
\text { failure scenarios. }\end{array}$ \\
\hline East Fork & $\begin{array}{l}\text { - Primary graded site of } 230+\text { acres is possible } \\
\text { - Cost to rough grade } 135 \text { acres (ele } 800 \mathrm{ft} \text { ) is estimated @ } \\
\$ 9,450,000 \\
\text { - Additional grading is required to level other sites: } 65 \text { Ac @ } \\
\$ 3,640,000 \text {, and } 30 \mathrm{Ac} @ \$ 1,470,000 \text {. }\end{array}$ & $\begin{array}{l}\text { - East Fork } 100 \text {-year flood varies from ele } 750 \mathrm{ft} \text { in the west } \\
\text { to ele } 770 \mathrm{ft} \text { in the east. } \\
\text { - Tracts must be configured substantially above the flood } \\
\text { zone. } \\
\text { - Largest upland tract would be approximately } 300 \mathrm{Ac} \text {. }\end{array}$ \\
\hline
\end{tabular}




\section{Comparative Site Assessment Transportation}

\begin{tabular}{|c|c|c|}
\hline & Highway & Rail \\
\hline Clinch Bend & $\begin{array}{l}\text { The } 9,000 \mathrm{ft} \text { access from State Route } 58 \text { to the leveled } \\
\text { primary site area would require up to two years to construct. } \\
\text { - Cost of four-lane access is estimated at } \$ 3,885,000 \text {. } \\
\text { - Cost to extend access to serve additional sites is: } 70 \text { Ac @ } \\
\$ 400,000 \text {; and } 30 \text { Ac @ } \$ 400,000 \text {. } \\
\text { - State's upgrading of SR } 58 \text { to } 4 \text { lanes from I- } 40 \text { is under way, } \\
\text { and includes a new intersection with the site access road. No } \\
\text { cost is included here }\end{array}$ & $\begin{array}{l}\text { Extending Norfolk Southern track to the graded primary } \\
\text { site requires construction of } 20,000+\text { feet of bed and track, } \\
\text { modification of bridge at SR 58, spur track around DOE } \\
\text { facility (K-25),switches and grade crossings @ } \$ 5,160,000 \text {. } \\
\text { - Additional cost to extend service to other sites: } 70 \text { Ac @ } \\
\$ 725,000 \text {, and } 30 \text { Ac @ } \$ 465,000 \text {. } \\
\text { - Outstanding safety issues through DOE property may be } \\
\text { difficult to resolve. Doe would also maintain some control } \\
\text { over line. }\end{array}$ \\
\hline Macedonia & $\begin{array}{l}\text { - Access would be from } 1-40 \text { via new 4-lane interchange at site } \\
\text { and new 2-lane access road to primary graded site. } \\
\text { - Total cost estimated at } \$ 3,830,000 \text {. } \\
\text { - Cost to extend access to serve other sites is: } 70 \text { Ac @ } \\
\$ 1,240,000 \text {, and } 36 \text { Ac @ } \$ 1,525,000 \text {. }\end{array}$ & $\begin{array}{l}\text { - Not rail-served. Extending the Norfolk Southern track to } \\
\text { the graded primary site would require the above } \\
\text { construction (Clinch Bend site), and a new Clinch River } \\
\text { bridge. } \\
\text { - Total additional cost @ } \$ 12,400,000 \text {. } \\
\text { - Additional cost to extend rail to other sites: } 70 \text { Ac @ } \\
\$ 375,000 \text {, and } 36 \text { Ac @ } \$ 35,000 \text {. }\end{array}$ \\
\hline Other Sites & $\begin{array}{l}\text { - Access would be from Route } 95 \text {, a two-lane highway that } \\
\text { expands to } 4 \text {-lane divided road at intersection with Route } 58 \\
\text { near western end of site, which limits curb cut options here } \\
\text { - Cost of four-lane access onto primary site area, including } \\
\text { bridge ( } \$ 1 \mathrm{MM}) \text { at East Fork is } \$ 1,496,000 \text {. } \\
\text { - } 3,000 \mathrm{ft} \text {. frontage road to serve smaller sites including the } \\
\text { western-most } 65 \mathrm{Ac} \text { tract is estimated @ } \$ 600,000 \text {. }\end{array}$ & $\begin{array}{l}\text { - Rail extension from west side of Poplar Creek requires a } \\
300 \mathrm{ft} \text {. trestle, and a second } 100 \mathrm{ft} \text {. trestle onsite is required } \\
\text { at East Fork. } \\
\text { Cost to serve primary site area including trestles and track } \\
\text { is } \$ 1,275,000 \text {. } \\
\text { - Cost to extend this rail southeast to serve two additional } \\
\text { tracts fronting Route } 95 \text { is: } \$ 498,000 \text { and } \$ 210,000 \text {. }\end{array}$ \\
\hline
\end{tabular}




\section{Comparative Site Assessment Energy}

\begin{tabular}{|c|c|c|}
\hline & Electric Power & Natural Gas \\
\hline Clinch Bend & $\begin{array}{l}\text { - TVA would construct } 161 \mathrm{kv} \text { looped service to site at no } \\
\text { cost to large user, }(>10 \mathrm{MW} \text { demand) from Bear } \mathrm{Cr} \text {. } \\
\text { Substation ( } 2.5 \mathrm{mi} \text {.) and Ft. Loudon Hydro (10 mi). } \\
\text { - Substation onsite has been dismantled. } \\
\text { - } 500 \mathrm{KV} \text { transmission traverses site. } \\
\text { - City of Oak Ridge would serve small user. }\end{array}$ & $\begin{array}{l}\text { - Oak Ridge Utility District serves Clinch River Industrial } \\
\text { Park, and will extend service to site or will construct new 6" } \\
\text { main ( } 350 \text { psi) from tap on East TN Natural Gas system } \\
\text { pipeline ( } 750 \text { psi) near SR 58, east of DOE K-25. } \\
\text { - No capital cost to large user. } \\
\text { - Firm gas supply contract is not available. }\end{array}$ \\
\hline Macedonia & $\begin{array}{l}\text { TVA would construct } 161 \mathrm{kv} \text { looped service to site at no } \\
\text { cost to large user, }(>10 \mathrm{MW} \text { demand) from Bear } \mathrm{Cr} \text {. } \\
\text { Substation. ( } 2.5 \mathrm{mi} \text {.) and Ft. Loudon Hydro }(10 \mathrm{mi}) \text {. } \\
\text { - } 500 \mathrm{KV} \text { transmission is } 0.5 \mathrm{mi} \text {. north of tract, or } 1.25 \mathrm{mi} \text {. } \\
\text { north of primary ( } 135 \mathrm{Ac} .) \text { site. } \\
\text { - Lenoir City would serve small user. }\end{array}$ & $\begin{array}{l}\text { Oak Ridge Utility District will construct service to the site as } \\
\text { above. Probable route will utilize the existing Clinch river } \\
\text { bridges. } \\
\text { - Firm gas supply contract is not available. }\end{array}$ \\
\hline East Fork & $\begin{array}{l}\text { - TVA } 161 \mathrm{kv} \text { dual feed or looped service to site is possible. } \\
\text { - Service for small users provided by City of Oak Ridge. }\end{array}$ & $\begin{array}{l}\text { - Oak Ridge Utility District will construct service to the site } \\
\text { from East TN Natural Gas system near Route } 58 \text {, } \\
\text { approximately } 4,500 \mathrm{ft} \text { west of site. } \\
\text { - Firm gas supply contract is not available. }\end{array}$ \\
\hline
\end{tabular}




\section{Comparative Site Assessment Water and Sewer}

\begin{tabular}{|c|c|c|}
\hline & Water & Sewer \\
\hline Clinch Bend & $\begin{array}{l}\text { - City of Oak Ridge would supply water from the existing } \\
\text { DOE treatment plant, using existing DOE } 8^{\prime \prime} \text { main to site } \\
\text { area. } \\
\text { - Pipe must be dedicated to the city. } \\
\text { - Requires two pump stations, new onsite pipeline and } 1 \mathrm{MG} \\
\text { storage tank; facility costs estimated @ } \$ 442,000 \text {. } \\
\text { - Capital cost to serve additional sites: } 70 \mathrm{Ac} @ \$ 65,000 \text {; and } \\
30 \mathrm{Ac} @ \$ 55,000 \text {. }\end{array}$ & $\begin{array}{l}\text { - To avoid discharge upstream of DOE freshwater intake, } \\
\text { would utilize City of Oak Ridge treatment plant at Bear } \\
\text { Creek Road. } \\
\text { - Plant must be expanded initially by } 500,000 \mathrm{gpd} \text {. } \\
\text { - Capital cost est. @ } \$ 1,250,000 \text { Usage est. @ } \$ 2.15 / 1,000 \mathrm{gal} \\
\text { - Separate sanitary and domestic wastewater lines and } \\
\text { pump stations would be constructed onsite, and extended } \\
\text { to the treatment plant, at a cost of } \$ 380,000 \text {. } \\
\text { - Cost to serve additional sites: } 70 \text { Ac @ } \$ 150,000 \text {, and } 30 \text { Ac } \\
\text { (1) } \$ 140,000 \text {, plus } \$ 650,000 \text { to expand treatment. }\end{array}$ \\
\hline Macedonia & $\begin{array}{l}\text { - Water source same as above, but requires longer and larger } \\
\text { pipeline and special river crossing, @ } \$ 903,000 \text {. } \\
\text { Capital cost to serve additional sites: } 70 \mathrm{Ac} @ \$ 55,000 \text {, and } 30 \\
\text { Ac @ } 15,000\end{array}$ & $\begin{array}{l}\text { Treatment plant and separate sanitary and domestic } \\
\text { wastewater pipelines to be constructed onsite. } \\
\text { - Cost estimated @ } \$ 1,440,000 \text {. } \\
\text { - Discharge into Clinch River at site requires NPDES permit. } \\
\text { DOE may object to discharge upstream of their freshwater } \\
\text { intake. Also Army Corps of Engineers permit of } \\
\text { intake/outfall structures. } \\
\text { - Cost to serve additional sites: } 70 \text { Ac @ } \$ 100,000 \text {, and } 30 \mathrm{Ac} \\
\text { @ } \$ 150,000 \text {, plus } \$ 625,000 \text { to expand treatment plant. }\end{array}$ \\
\hline East Fork & $\begin{array}{l}\text { - Water source is same as above, from existing DOE } 10 \text {-inch } \\
\text { line } 7,000 \mathrm{ft} \text { west of the site. Capital cost to serve primary } \\
\text { site and smaller frontage sites, including pipe, tank and } \\
\text { pump estimated @ } \$ 780,000 \text {. } \\
\text { Additional } \$ 25,000 \text { to serve isolated } 20 \text { Ac tract at east end of } \\
\text { site. }\end{array}$ & $\begin{array}{l}\text { - Waste is pumped to existing City of Oak Ridge treatment } \\
\text { plant east of site, utilizing new forced main and minor } \\
\text { system upgrades. } \\
\text { - Capital cost estimated @ } \$ 725,000 \text { for the primary site. } \\
\text { - No additional cost to serve smaller tracts fronting Route } 95 \text {. }\end{array}$ \\
\hline
\end{tabular}




\section{Comparative Site Assessment}

Constraints on Acquisition \& Development

\begin{tabular}{|c|c|c|}
\hline & Regulatory Constraints & Land Ownership \\
\hline Clinch Bend & $\begin{array}{l}\text { - No significant impediments to development have been } \\
\text { identified. } \\
\text { TVA must prepare environmental assessment (EA) if / when } \\
\text { site is sold, cost estimated @ } \$ 50,000 \text {, assuming use of prior } \\
\text { EA. } \\
\text { - Some ambient air data for TN air permits may be readily } \\
\text { available from TVA -- estimated value @ } \$ 50,000 \text {. }\end{array}$ & $\begin{array}{l}\text { - One owner, TVA, is willing to sell. } \\
\text { TVA will likely place constraints on using certain lands for } \\
\text { industrial purposes, to protect natural areas, slopes, ridges, } \\
\text { etc. in keeping with its federal mandate to improve the } \\
\text { quality of life for inhabitants of the region. }\end{array}$ \\
\hline Macedonia & $\begin{array}{l}\text { - Property not owned or permitted by federal agencies, } \\
\text { therefore it is not directly subject to federal statutes. } \\
\text { - No significant impediments to development have been } \\
\text { identified, but cultural resources may delay development. }\end{array}$ & $\begin{array}{l}\text { Estimated } 26 \text { owners ( } 7 \text { on primary site). TVA owns } \\
\text { waterfront land. } \\
\text { Existing homes will complicate or delay site acquisition. It } \\
\text { may be possible to avoid Buttermilk Shores subdivision (17 } \\
\text { tracts, } 5 \text { existing homes) if no rail access/river crossing is } \\
\text { constructed. }\end{array}$ \\
\hline East Fork & $\begin{array}{l}\text { - No significant impediments to development have been } \\
\text { identified. } \\
\text { - DOE must prepare environmental assessment (EA) if/ when } \\
\text { site is sold, cost estimated @ } \$ 100,000 \text {. } \\
\text { - Some ambient air data for TN air permits may be readily } \\
\text { available - estimated value @ } \$ 50,000 \text {. }\end{array}$ & $\begin{array}{l}\text { - DOE is the sole owner. } \\
\text { - Willingness to sell may be greater at the upper levels of } \\
\text { management, questionable at lower levels in the DOE } \\
\text { organization. }\end{array}$ \\
\hline
\end{tabular}




\section{Comparative Site Assessment Land Cost \& Potential Selling Price to User}

\begin{tabular}{|c|c|c|}
\hline & Current Estimated Selling Price / Acre & $\begin{array}{c}\text { Developed Site -- Price Per Acre to User } \\
\text { (See: Differential Development Costs following page) }\end{array}$ \\
\hline Clinch Bend & $\begin{array}{l}\text { - Estimated price } \$ 2,000,00 \text { for } 1,200 \text { Ac. } \\
\text { - Average price }=\$ 1,660 / \text { Ac. }\end{array}$ & 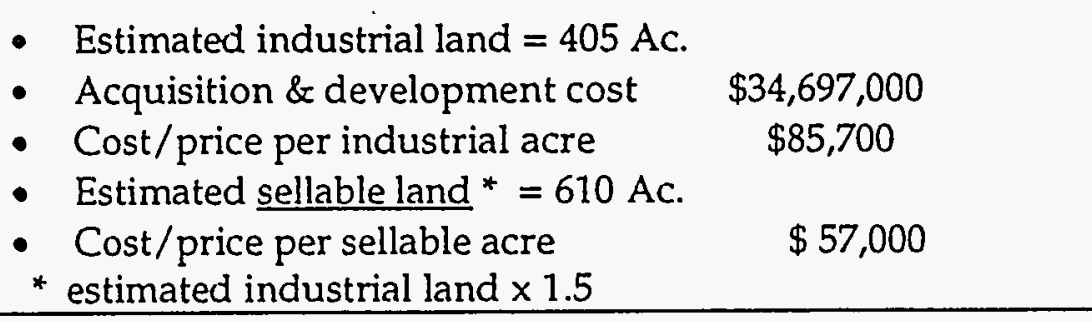 \\
\hline Macedonia & $\begin{array}{l}\text { Estimated price } \$ 5,130,000 \text { for } 1,000 \mathrm{Ac} \text {. } \\
\text { - Average price }=\$ 5,130 / \text { Ac. }\end{array}$ & 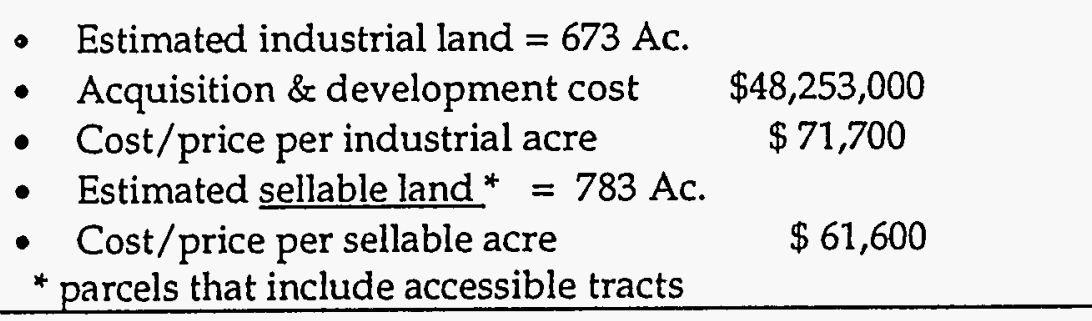 \\
\hline East Fork & $\begin{array}{l}\text { - No asking price. Assume } \$ 5,000 \text { per acre of buildable land } \\
\text { (estimated } 540 \mathrm{Ac} \text { ) would result in } \$ 2,700,000 \text { for the entire } \\
\text { tract. } \\
\text { Average price }=\$ 3,375 / \text { Ac. }\end{array}$ & 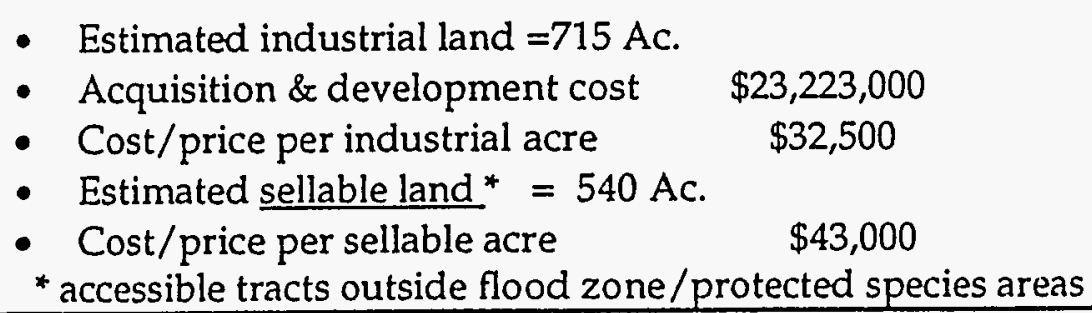 \\
\hline
\end{tabular}




\section{Relative Site Rankings}

Corporate Perception of Suitability

\begin{tabular}{l|cccccccccc}
\hline \multicolumn{1}{c|}{ Site } & $\begin{array}{c}\text { Size, } \\
\text { Config. }\end{array}$ & Image & $\begin{array}{c}\text { Grading } \\
\text { Flooding }\end{array}$ & Access & Energy & $\begin{array}{c}\text { Water } \\
\text { Sewer }\end{array}$ & $\begin{array}{c}\text { Environ- } \\
\text { mental }\end{array}$ & $\begin{array}{c}\text { Acquisition } \\
\text { Constraints }\end{array}$ & $\begin{array}{c}\text { User } \\
\text { Land } \\
\text { Cost }\end{array}$ & $\begin{array}{c}\text { Overall } \\
\text { Rank }\end{array}$ \\
\hline Clinch Bend & C & B & B & B & A & B & B & A & B & B \\
East Fork & A & A & B & A & A & A & B & A & A & A \\
Macedonia & B & A & C & C & B & C & B & C & C & C \\
\hline
\end{tabular}

Criteria Ranks:
A Most favorable perception
B Perceived as acceptable
C Perceived as less acceptable 


\section{Overall Comparison of Alternatives}

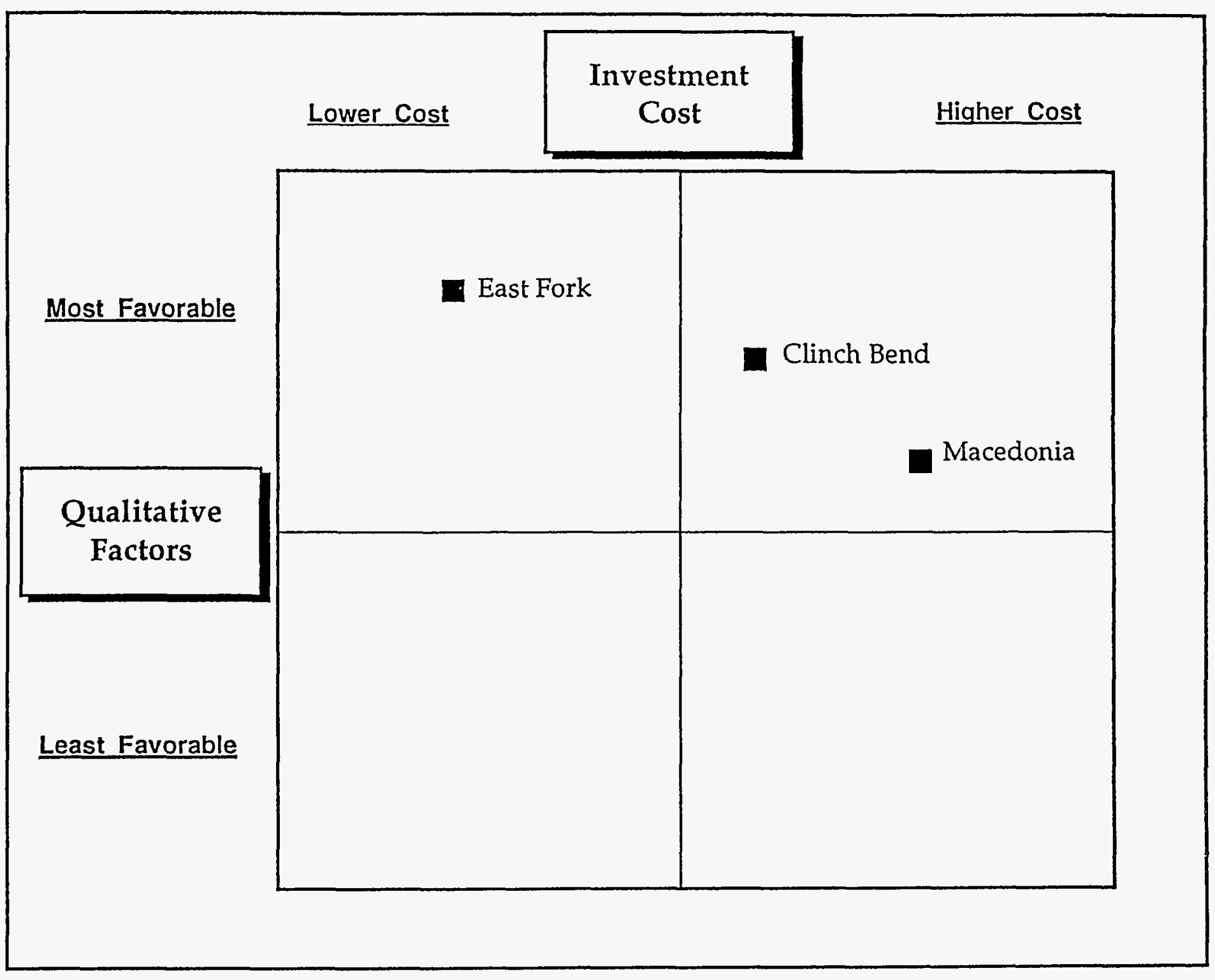




\section{Conclusion - Clinch Bend Site Marketability}

Lockwood Greene's assessment of Oak Ridge area sites reveals that the Clinch Bend Site offers a number of advantages for manufacturing companies which require a location upon which to base a long-term investment strategy. There are also liabilities at this location, to be sure, but given the alternatives considered herein and based upon Lockwood Greene's experience, the advantages appear to be significant.

Site marketability can be improved through investment to mitigate negative aspects of the site or environs, and to enhance the assets present therein. Improvements that the Chamber may want to consider are indicated. The costs of such investment mount rapidly; however, and a point of diminishing return is reached before all of the liabilities are fully addressed. Much is achievable within this limit though, as the following discussion -demonstrates.

Site marketability issues are summarized in the matrix on the following two pages. Marketability as presented herein is an abstract concept and much depends on the implementation of a marketing campaign designed to capture the site's strengths and present these to prospective companies. 


\section{Clinch Bend Site Marketability}

"As Is" and With Additional Investment to Overcome Liabilities

\begin{tabular}{|c|c|c|}
\hline & "As Is" & With Additional Investment \\
\hline $\begin{array}{l}\text { Site Size, } \\
\text { Image }\end{array}$ & $\begin{array}{l}\text { - High - single large user } \\
\text { - Moderate/High - large user requiring that a few } \\
\text { vendors or suppliers collocate nearby } \\
\text { - Low - user sensitive to competitive issues related to } \\
\text { perceptions of product safety/wholesomeness, e.g. } \\
\text { some food processing }\end{array}$ & $\begin{array}{l}\text { No investment recommended } \\
\text { Cannot change site configuration, area topography, } \\
\text { proximity to DOE facilities }\end{array}$ \\
\hline Topography & $\begin{array}{l}\text { - Moderate/Low - single medium size user, or } 2 \text { - } 3 \\
\text { small users }\end{array}$ & $\begin{array}{l}\text { High - single large user, or several medium users } \\
\text { Moderate - large user requiring several } \\
\text { vendor/suppliers collocate nearby }\end{array}$ \\
\hline $\begin{array}{l}\text { Highway } \\
\text { Access }\end{array}$ & - Moderate/Low - small, light traffic users only & - High - moderate and large users \\
\hline $\begin{array}{l}\text { Interstate } \\
\text { Access }\end{array}$ & $\begin{array}{l}\text { High - most facilities do not require interstate } \\
\text { visibility } \\
\text { - Low - industries driven by brand loyalty, e.g. } \\
\text { selected consumer products, automobiles, etc. that } \\
\text { require direct interstate visibility. }\end{array}$ & No investment recommended \\
\hline $\begin{array}{l}\text { Rail } \\
\text { Access }\end{array}$ & $\begin{array}{l}\text { - High - some light fabrication, assembly; technology- } \\
\text { driven } \\
\text { - Moderate/Low - medium \& heavy } \\
\text { manuf./assembly/ process; e.g. automotive, chemical, } \\
\text { construction products, paper }\end{array}$ & $\begin{array}{l}\text { - High - heavy manuf./assembly/ process manuf.; e.g. } \\
\text { automotive, chemical, construction products; paper } \\
\text { - Low - technology based, e.g. optics, semiconductor }\end{array}$ \\
\hline
\end{tabular}




\section{Site Marketability (contd.)}

"As Is" and With Additional Investment to Overcome Liabilities

\begin{tabular}{|c|c|c|}
\hline & "As Is" & With Additional Investment \\
\hline $\begin{array}{l}\text { Barge } \\
\text { Access }\end{array}$ & $\begin{array}{l}\text { - High - vast majority of operations do not require } \\
\text { barge terminal at the site } \\
\text { - Low - all barge users } \\
\end{array}$ & $\begin{array}{l}\text { No investment recommended. Problems in the canal/lock } \\
\text { system in general mitigate benefits of a barge terminal at } \\
\text { this site. }\end{array}$ \\
\hline Energy & $\begin{array}{l}\text { - High - most manufacturing operations do not require } \\
\text { firm natural gas delivery contracts }\end{array}$ & No investment recommended \\
\hline $\begin{array}{l}\text { Water } \\
\text { Sewer }\end{array}$ & $\begin{array}{l}\text { - High - selected very large process operations } \\
\text { accustomed to operating in-house water and } \\
\text { wastewater treatment plants } \\
\text { - Low - all other users }\end{array}$ & $\begin{array}{l}\text { High - all users requiring up to } 2 \text { million gallons/day } \\
\text { water, the limit of excess capacity at the K-25 treatment } \\
\text { plant }\end{array}$ \\
\hline $\begin{array}{l}\text { Environment } \\
\text { Air, Water }\end{array}$ & $\begin{array}{l}\text { - High - most manufacturing operations } \\
\text { - Low - food processors; selected users of groundwater, } \\
\text { e.g. some semiconductor manufacturers (re site's } \\
\text { proximity to DOE facilities) }\end{array}$ & $\begin{array}{l}\text { No investment recommended. } \\
\text { Modeling the groundwater plume would be prohibitively } \\
\text { time-consuming and costly. }\end{array}$ \\
\hline $\begin{array}{l}\text { Regulatory } \\
\text { Constraints }\end{array}$ & $\begin{array}{l}\text { - High - most light and heavy manufacturing } \\
\text { operations } \\
\text { Moderate - large process operations, others that emit } \\
>100 \text { tons/yr. volatile organic compounds, must use } \\
\text { state-of-the art technology }\end{array}$ & $\begin{array}{l}\text { No investment recommended. } \\
\text { VOC rule applies to entire state. }\end{array}$ \\
\hline $\begin{array}{c}\text { Site } \\
\text { Acquisition }\end{array}$ & $\begin{array}{l}\text { - High - all users } \\
\text { Single owner is a definite advantage. }\end{array}$ & No investment recommended. \\
\hline
\end{tabular}




\section{Site Marketing Strengths}

The key issues that favor investment by manufacturing companies at the Clinch Bend Site and which should be stressed in a marketing campaign are:

- Ready availability

- Proximity to rail and interstate highway system

- Barge access

- Access to markets

- Existing energy facilities

- Well-documented environmental issues

- Business/plant operating environment

\section{Ready Availability}

Control of the site by a single owner, TVA, is a major positive factor. The TVA's Watts Bar Reservoir Land Use Plan states the site "is being promoted for industrial use". TVA is actively marketing the site for this purpose. The City's industrial zoning designation also reflects industrial use. It is difficult to find another site of this size in the region which is considered to be similarly available.

Site availability plays an important role in the corporate site decision. Since the site acquisition program is often on a compressed schedule, anything with potential to delay or derail the schedule is viewed with great concern. TVA's ownership of the Clinch Bend site and its professed interest in selling the property for industrial use is probably the second-best arrangement possible, ranking behind outright community control.

\section{Proximity to Markets via Rail and Interstate Highway System}

Access to both rail service and the interstate highway system at a single location is an unbeatable combination. The site is not simply near these features, it has been shown to be accessible to them. This is important for several reasons:

- It significantly reduces the perceived risk to prospective users, that rail can actually be extended to the site in a timely fashion.

- It links the site with the expanding Southern US markets, and Gulf Coast and Eastern ports. 
- Manufacturers desire access to two modes of transportation, because it provides flexibility in logistical decisions and enhances a manufacturer's ability to negotiate favorable transportation rates. This can significantly reduce operating costs for some operations.

\section{Port/Barge Access}

Barge access is certainly a selling point, but it is not considered a major asset. The Clinch River at this point is relatively narrow for barge docking and navigation, forcing the potential barge terminal onto a small tract of land that is actually some 4,500 feet north of the primary graded site area. This requires constructing and operating a rail or conveyor system to the plant site. Also, barge traffic on the Tennessee River north of Chattanooga is constrained by Chickamauga Lock, a 60' $x$ $360^{\prime}$ chamber constructed in 1940. This structure can accommodate only a single barge. The problem is repeated at Watts Bar Lock. This results in a delay in transit of up to 8 hours for a typical 8-barge fleet, and a corresponding increase in cost.

\section{Existing Energy Facilities}

The close proximity of major electric power transmission facilities with the potential for looped feed is a key asset because it occurs in conjunction with several other necessary factors of production for large users, that is, rail service, interstate routes, and a reasonably large, buffered site. Electric transmission capacity at this point on the TVA system was designed to supply the large energy requirements at ORNL and DOE facilities. It would be unusual for an industrial user to judge this system to be inadequate to support operations at the site.

Natural gas service at the site is likewise attractive to users planning on a rapid facility start-up. Only the addition of firm gas supply to this point on the transmission system would improve the situation. Many large gas users address the firm supply issue by negotiating for gas supply and storage directly with the pipeline company, and utilize the local distribution company for transportation only.

\section{Documented Environmental Issues}

The wealth of environmental documentation available from TVA, the State of Tennessee and others is significant, because it can mitigate the corporate perception of risk. A corporate decision to invest in a site is made in the earliest stages of a much larger decision involving a range of investments in technology, facilities, marketing, etc. However, the site decision is of ten made first, prior to expending corporate resources on these other factors, thus it tends to be an early focal point of corporate cost-benefit analysis. It can also be the focus of internal divisions in the corporate hierarchy, and stimulate internal objections that have little to do with the site issue itself. 
Under these circumstances any perceived risks are given heavy weight, and may be used by one faction to derail the project at a location. Since the lack of information is itself often interpreted as a risk, a comprehensive data base on the site can be a useful tool to mitigate these concerns, at the appropriate point in the process.

\section{Business Operating Environment}

The site is in a region that in Lockwood Greene's experience is regularly considered for new plants and expansions. The site itself is also attractive to foreign companies, as evidenced by the close scrutiny of the site by Mercedes. Foreign investment is likely to remain an important factor in economic development, particularly in light of continuing changes in currency valuations.

Interviews conducted by Lockwood Greene in Oak Ridge and the Greater Knoxville area, and discussions with employers from outside the area who maintain facilities there, reveal a high regard for the attitudes and abilities of the local work force. Foreign and domestic companies conducting an examination of the critical labor force issues, including labor-management relations in manufacturing, will find only four NLRB certification elections in ten years, resulting in one certification.

While the site is within a major metropolitan area, it is not under the influence of other major manufacturers, and is attractive to companies that may desire to institute innovative labor-management relationships and work methods.

\section{Site Marketing Weaknesses}

As evidenced by the preceding discussion, important success factors that drive corporate site decisions can be achieved in the process of developing the site for industrial uses. Even so, Lockwood Greene has identified several issues that can work against investment by manufacturing companies at the Clinch Bend Site.

These are:

- Site development cost factors

- Limitations on land area and site flexibility

- Perceived environmental risk

- Lack of visibility from intestate highway

- Commercial airline service

\section{Site Development Cost Factors}

The cost of improving the site has major implications for marketability, because it drives up the selling price of the land. This has two general consequences: 
- If the entire cost of improving the site is to be recaptured through land sales, then the site may not be cost competitive with other sites in the southern US.

- If the site is to attract corporate investment, then the effect of this high cost on the project economics must be mitigated by a compensating advantage at this location, e.g. lower labor costs, transportation costs, etc. for the operation in question.

- Even if operating cost savings achievable at this site mitigate the disadvantage over time, the initial high nonrecurring cost will reflect negatively on the site for some companies.

- The point at which this nonrecurring cost becomes "excessive" varies for different projects, but generally it depends on two factors:

- Payback period. The time required to recapture the nonrecurring costs associated with a relocation or start-up, through the savings in operating costs. This is generally in the range of 3 to 5 years.

- Project financing. This may dictate a necessary rate of return on the investment, which varies considerably by company.

- If Oak Ridge elects not to recapture all of the improvement costs, but to treat a major portion as basically nonrecoverable, the site can be more competitively marketed, but this has certain other implications that tend to overcome this advantage in the long run:

- There will be little, if any, community capital remaining to "sweeten the pot" during the critical negotiations that will occur after the site qualifies for inclusion in the company's "short list", or to take advantage of other economic development opportunities that come along. Oak Ridge will have placed all its eggs in a single basket.

- It would not be cost-effective to use the site for projects that do not generate a high return on the community's investment, such as highpaying jobs or tax revenues, or otherwise generate a rate of return sufficient to offset this cost. Oak Ridge would need to target the site only to facilities that meet these stringent criteria.

These costs are based on improvements that for the most part must be undertaken, but there is some flexibility regarding (1) who pays for them, and (2) when. In Lockwood Greene's opinion this issue has the potential to seriously affect the desirability of proceeding at this location as envisioned. The potential costs of preparing a ready-to-go site and recommendations on how these may be managed are addressed in detail in the next section of this report. 


\section{Limitations on Land Area and Site Flexibility}

The site is not expandable beyond approximately 400 acres of industrial land, with about 300 acres of this in a single tract. In Lockwood Greene's experience 300 acres is approximately the minimum acreage sought by very large projects The effect of this limitation is a slight reduction in the potential number of manufacturing projects for which the site can successfully compete. This is a major consideration in Lockwood Greene's decision not to recommend investments in major river crossings, e.g. interstate highway access, at this time. From a site size perspective, the investment would be of questionable value The effect of this recommendation is to help keep the site competitive from a cost standpoint for the many types of projects which can be accommodated on the land available.

\section{Perceived Environmental Risk}

The unreclaimed breeder reactor excavation on the site is a continuing reminder of the nuclear safety issue and provides prospective companies with a visible focal point for such concerns.

Proximity to nuclear facilities formerly or presently operated by ORNL/DOE, and other nearby facilities, will cause some concern regarding offsite contamination from these installations, particularly water-born pollution. This does not appear to be warranted, and a good information campaign should be adequate to manage these concerns for most, but probably not all, prospective companies.

- Although nuclear weapons material is no longer produced here, the entire Oak Ridge facility is on the EPA Superfund National Priority List. Water pollution does not appear to be a health threat or operating concern, as is demonstrated by groundwater, surface water and shallow water sediment samples analyzed for previous environmental studies at the Clinch Bend Site. The groundwater plume does not appear to have been modeled, but environmental studies have determined that groundwater flow in the site vicinity is normal, that is, from higher elevations toward lower elevations. This should cause any pollution from these facilities to flow downstream (west) away from the site.

- Scientific Ecology Group, Inc. operates a low level radioactive waste processing facility at Bear Creek Road approximately 3,500 feet north of the site. The company reportedly has a clean safety record.

- ORNL continues to operate the High Flux Isotope Reactor, constructed in the 1960 's and closed for a time in the 1980's because of reactor vessel embrittlement.

- From time to time there is talk of moving high level radioactive waste processing or nuclear weapons "reconfiguration" operations onto the DOE K-25 site. 
- In the unlikely event of a declared emergency at DOE/ORNL that requires evacuating this site, site egress would be to the north, toward the threat.

\section{Lack of Visibility From Intestate Highway}

Lack of interstate visibility cannot be mitigated. There is no mechanism to adequately compensate for this, and companies that require it will not consider the site. In Lockwood Greene's experience this probably represents less than $5 \%$ of all industrial projects.

\section{Commercial Airline Service}

Companies that are located in major markets, with managers accustomed to direct commercial airline service to business destinations, may have reservations about locating a major facility here. The issue is more prevalent among office and research $\&$ development facility managers than manufacturing. In many instances this concern has been negated by actual experience, and that is likely to happen here after they experience the reliable jet service offered at McGhee-Tyson Airport. For others; however, the site will be found lacking in this regard and no mitigation is possible. 
Investment decisions for economic development projects of this magnitude can gain enormous benefit by using a framework for objectively reviewing the effort required and the costs incurred to deliver the site to market. The initial planning assumptions and projections set forth in this framework can then be modified if necessary to accommodate revisions in community objectives and perceived opportunities over time.

Lockwood Greene's recommendation to invest in certain onsite improvements and enhancements to area and regional infrastructure is made based on a comparison of:

- The needs of manufacturers identified as likely to seriously consider the site

- Assessment of factors already adequately represented, either in-place or that are readily deliverable

- Estimated cost of the improvements necessary to increase the site's ability to satisfy projected users' need's

- Projected revenue stream to the community from land sales to site users.

Based on Lockwood Greene's assessment of these factors, several key issues are identified and conclusions and recommendations made for the development of the Clinch Bend site.

\section{Existing Site Infrastructure and Investment}

Previous development activities at the site, while not resulting in placement of industrial facilities, do have value and can be recognized for their contribution to lowering development costs and enhancing the site for other prospective users. These are:

- Preconstruction ambient air quality monitoring data previously obtained by TVA at the site

- If available and useful in its entirety, is valued at between $\$ 70,000$ and $\$ 100,000$ (Tennessee Department of Environment and Conservation) 
- NEPA requires TVA to complete an environmental assessment (EA) before property can be transferred to another owner or committed to another use. A typical EA would cost approximately $\$ 100,000$.

- TVA has completed an EA for a previous project on the site, which reduces the investigations and analysis necessary for the present project, and correspondingly reduces the cost to approximately $\$ 50,000$ (TVA)

- The relatively "clean" EA of prior years may be most valuable as a marketing tool, particularly for projects on a "fast track".

- This "saving" may be illusory, since an EA would not be required at another site that does not involve federal agency ownership or permit authority. On the other hand, if federal funds are used to acquire or develop another site, it could trigger the NEPA review process there as well.

Unfortunately, these investments are not considered to be a major beneficial factor in light of the "disinvestment" represented by the existing excavation that may need to be landscaped or reclaimed if a major user is to be attracted to the site.

\section{Site Configuration and Development Sequencing}

The largest single land use category appropriate for industrial development as well as the prevailing land form at this location is "buffer". Of the 1,200 acres that comprise the site, approximately 800 acres are too rough or are environmentally sensitive for industrial uses. Fortunately, the developable industrial land is virtually surrounded by this remaining land or by the Clinch River. From the view point of manufacturing concerns, this forms a logical buffer. Some, but not all, of this acreage would probably be included in the land requirement at any other location as well.

Areas which are considered suitable for industrial development are basically those which, on the face of it, can be brought to market in a reasonable time and at a reasonable cost. Consideration of the land areas at Clinch Bend which are initially determined suitable for industrial development lead to the following conclusions:

- Clinch Bend site configuration and topography strongly suggest that the site is unlikely to be fully occupied by a single user, but that it is better suited for at least two or three sites serving different manufacturing operations. 
- The primary site would consist of the largest and best positioned of these areas:

- Approximately 130 acres on a 205-acre tract (which is the northern portion of an approximately 305 -acre tract).

- Closest to rail, highway access, water and sewer.

- A secondary site would consist of a smaller and somewhat less desirable area:

- Approximately 70 acres to be graded on a 100 -acre tract.

- 3,500 feet east of the primary site and not easily accessible.

- Requires extension of all infrastructure and utilities beyond the primary site at additional cost.

- Another secondary site would consist of the southern portion of the above-cited 305-acre tract :

- Approximately 30 acres to be graded on a 95-acre tract.

- In close proximity to the primary site but at a different elevation.

- The site is not accessible by commercial truck or rail at present, and this would have to be developed to attract a major user. Even smaller users would require investments in water, sewer, and electric power extensions to the site.

- Initial investment in site grading and infrastructure is larger than can be justified by only a small user or several small users scattered over the site.

- Locating smaller industries initially, before attempting to market larger users, would have several undesirable effects:

- The site configuration selected for a small user could preclude maximizing the configuration for larger users.

- imposing an undesirable cost or operating penalty on large operations

- burdening the site with a competitive disadvantage for large users

- Increasing the initial investment costs because secondary sites are farther from the existing infrastructure

- Therefore, the initial user should be a relatively large industry:

- This assures maximum flexibility in accommodating large user needs regarding placement and configuration. 


\section{Recommended Additional Infrastructure and Site Improvements}

Lockwood Greene recommends that investment in land acquisition, onsite improvements, and infrastructure connecting the site with required offsite services be undertaken consistent with the multiple-user development configuration outlined above. It is not necessary or desirable to prepare the entire site for occupancy at one time. It can be phased-in as needed to accommodate the demand for land.

- The phases of development are intended to reflect a balance between the needs of a marketing campaign (producing a tangible asset that prospective companies can relate to ) and the lead time needed to actually service a manufacturing facility.

- While a certain level of investment is necessary to attract industrial prospects, the actual construction of improvements, etc. can be delayed until a commitment or purchase agreement is reached with the prospective facility owner, thereby reducing the risk to public agencies and service providers. Unfortunately, the most expensive investment is also the one that is likely to be required first, that is, the rough grading for the primary site.

- Some of the proposed improvements should be undertaken only after the specific requirements of industrial users that will occupy the site are known and understood.

- The completion of each phase should be reflected in the marketing program for subsequent phases. 


\section{Investment Phases - Full Development}

\begin{tabular}{|c|c|c|}
\hline Phase 1 & $\begin{array}{l}\text { Prior to a purchase agreement } \\
\text { with site user }\end{array}$ & $\begin{array}{l}\text { - Rough grade up to } 100 \mathrm{Ac} \text {. on the primary } \\
\text { site } \\
\text { - Upgrade 4-lane access from site to State } \\
\text { Route } 58 \\
\text { - Construct onsite portion of road access to } \\
\text { primary site area } \\
\text { - Engineer rail spur and siding, prepare } \\
\text { display-quality maps showing } \\
\text { hypothetical site layout, e.g. } 500,000 \mathrm{sf} \\
\text { building } \\
\text { - Commission an environmental assessment }\end{array}$ \\
\hline Phase 2 & $\begin{array}{l}\text { At signing of purchase } \\
\text { agreement for primary site }\end{array}$ & $\begin{array}{l}\text { - Construct onsite and offsite water supply } \\
\text { pumping stations and line from the K-25 } \\
\text { treatment plant } \\
\text { - Construct onsite and offsite rail } \\
\text { - Construct onsite and offsite sewer lines to } \\
\text { Bear Creek treatment plant } \\
\text { - Upgrade Bear Creek sewage treatment } \\
\text { plant } \\
\text { - Engineer rail service, as above, for a } \\
\text { secondary site }\end{array}$ \\
\hline Phase 3 & $\begin{array}{l}\text { At completion of the first site } \\
\text { development program }\end{array}$ & $\begin{array}{l}\text { - Construct onsite road access to the } \\
\text { - } \text { secondary site area(s) not yet served } \\
\text { - Rough grade all secondary sites }\end{array}$ \\
\hline Phase 4 & $\begin{array}{l}\text { At signing of purchase } \\
\text { agreement for any secondary } \\
\text { site }\end{array}$ & $\begin{array}{l}\text { Extend water, sewer, rail to secondary site } \\
\text { areas }\end{array}$ \\
\hline
\end{tabular}




\section{Investment Costs and Projected Revenue}

The main portion of the site could conceivably be occupied by one or two users. Indeed, the marketing campaign can be structured with this as an objective (large users). This approach may yield the fastest utilization of the site and quickest return on the investment. If it is determined that smaller users can be successfully marketed and there are no larger projects on the horizon, a decision must be made as to the risk that this would pose for marketing the remainder of the site to a larger user. Perhaps by using the periphery of the site or focusing on one of the remote areas, e.g. the 100 acre tract east of the primary site, this can be accomplished.

All that is needed after the community has completed this work is for the owner to produce a plant design and site layout, and construction can begin. This is the ideal situation for the prospective user because it minimizes lead time to start-up, and essentially removes many of the risks associated with site preparation. In short, it enhances Oak Ridge's competitive position vis a vis other communities.

The problem with this approach at the Clinch Bend Site is likely to be the high selling price of the land after this investment has been incurred. The selling price per acre is determined in part by (1) the land area that is judged to be marketable under any realistic scenario, and (2) the total cost to the community to purchase and develop the site sufficiently to convert it into a marketable commodity.

The costs of undertaking the recommended investments in the Clinch Bend Site and the effects this has on the cost of land to the user are shown on the following tables.

Of the 1200 acres contained within the TVA's property here, which is within the Watts Bar Reservation, most cannot be developed for industrial or other intensive uses due to environmental constraints reflected in the Watts Bar Reservoir Land Use Plan, and the topographic constraints on construction. The total estimated industrial land area used in this analysis, 405 acres, is the basis for the land area that is estimated to be marketable. Specifically, it is assumed that a willing buyer will, if necessary, purchase acreage that is equal to about $150 \%$ of the industrial land area actually contained therein, but is not likely to go much higher than this number. Keep in mind that the buildable (graded) area on this "industrial" land is generally only $50 \%$ to $70 \%$ of the industrial acreage. The remainder is marginally suited for parking, small ancillary facilities, etc. Thus, under this assumption the ratio of purchased land to buildable land will probably not be better than 2.5:1.

This means that only approximately 610 acres of the Clinch Bend Site is considered marketable to industrial users. 


\section{Site Investment Cost \\ $(\$ 000)$ \\ Maximum (3-tract) Configuration}

\section{Site}

Land Acquisition

Rough Grading (1) subtotal

\section{Utilities}

Water Service

Wastewater Service

Natural Gas Service

Clinch

East

Bend Macedonia Fork

Electric Power Service subtotal

Access

Highway (2)

Rail

$$
2,000
$$

18,480

5,130

2,700

20,480

20,280

14,840

subtotal

$\begin{array}{rrr}562 & 973 & 778 \\ 2,570 & 2,315 & 726 \\ 0 & 0 & 0 \\ 0 & 0 & 0 \\ 3,132 & 3,288 & 1,504\end{array}$

$$
4,685
$$

6,595

2,096

6,350

12,810

1,983

11,035

19,405

4,079

Environmental

Environmental Assessment

Ambient Air Monitoring

Archaeology

subtotal

$$
50
$$

0

100

$\begin{array}{rrr}0 & 0 & 0 \\ 0 & 150 & 0 \\ 50 & 150 & 100\end{array}$

\section{Total Investment}

$\$ 34,697 \quad \$ 48,253 \quad \$ 23,223$

Notes:

(1.) Excludes cost to landscape/reclaim existing excavation at Clinch Bend.

(2) Direct interstate connection at Macedonia site. 


\section{Clinch Bend Investment Schedule \\ $(\$ 000)$}

Improvements

\begin{tabular}{|c|c|c|c|c|c|}
\hline \multirow[t]{2}{*}{ Improvements } & & \multicolumn{4}{|c|}{ Investment Phase } \\
\hline & & Phase 1 & Phase 2 & Phase 3 & Phase 4 \\
\hline \multicolumn{6}{|c|}{ 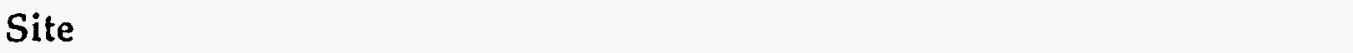 } \\
\hline Land Acquisition & $1,200 \mathrm{Ac}$. & 2,000 & & & \\
\hline \multirow[t]{3}{*}{ Rough Grading (1) } & $130 \mathrm{Ac}$ & 9,900 & & & \\
\hline & $70 \mathrm{Ac}$ & & & 5,880 & \\
\hline & 30 Ac. & & & 2,700 & \\
\hline \multicolumn{6}{|l|}{ Utilities } \\
\hline \multirow[t]{3}{*}{ Water Service } & $130 \mathrm{Ac}$. & & 442 & & \\
\hline & 70 Ac. & & & & 65 \\
\hline & 30 Ac. & & & & 55 \\
\hline \multirow[t]{3}{*}{ Wastewater Service } & $130 \mathrm{Ac}$. & & 1,630 & & \\
\hline & 70 Ac. & & & & 800 \\
\hline & $30 \mathrm{Ac}$. & & & & 140 \\
\hline Natural Gas Service & & & 0 & & \\
\hline Electric Power Service & & & 0 & & \\
\hline \multicolumn{6}{|l|}{ Access } \\
\hline \multirow[t]{3}{*}{ Highway } & $130 \mathrm{Ac}$. & 3,885 & & & \\
\hline & 70 Ac. & & & 400 & \\
\hline & $30 \mathrm{Ac}$ & & & 400 & \\
\hline Rail - engineer & 130 Ac. & 0 & & & \\
\hline Rail - construct & 130 Ac. & & 5,160 & & \\
\hline Rail - engineer & 30,70 Ac. & & 0 & & \\
\hline \multirow[t]{2}{*}{ Rail - construct } & $70 \mathrm{Ac}$ & & & & 1,190 \\
\hline & 30 Ac. & & & & \\
\hline \multicolumn{6}{|l|}{ Environmental } \\
\hline Environmental Assessment & - & 50 & & & \\
\hline Total & & $\$ 15,835$ & $\$ 7,232$ & $\$ 9,380$ & $\$ 2,250$ \\
\hline Cumulative Investment & & $\$ 15,835$ & $\$ 23,067$ & $\$ 32,447$ & $\$ 34,697$ \\
\hline
\end{tabular}

Notes:

(1) Excludes cost to landscape/reclaim existing excavation on the site. 


\section{Clinch Bend Site \\ Project Costs and Land Sale Revenue}

Phase 1 Phase 2 Phase 3 Phase 4 Phase 4t

Revenue from Land Sales

Plant site - graded acres (1)

Acres in total tract sold

Selling price/acre $(\$ 000)$

Revenue this phase $(\$ 000)$

Cumulative revenue

Inveștment $(\$ 000)$

This phase

Cumulative investment

$\begin{array}{rrrrrr} & 130 & & 40 & 30 & 30 \\ & 330 & & 100 & 90 & 90 \\ & \$ 57 & & \$ 57 & \$ 57 & \$ 57 \\ \$ 0 & \$ 18,810 & \$ 0 & \$ 5,700 & \$ 5,130 & \$ 5,130 \\ \$ 0 & \$ 18,810 & \$ 18,810 & \$ 24,510 & \$ 29,640 & \$ 34,770\end{array}$

$\begin{array}{rrrrrr}\$ 15,835 & \$ 7,232 & \$ 9,380 & \$ 2,250 & \$ 0 & \$ 0 \\ \$ 15,835 & \$ 23,067 & \$ 32,447 & \$ 34,697 & \$ 34,697 & \$ 34,697\end{array}$

$\begin{array}{lllll}(\$ 15,835) & \$ 11,578 & (\$ 9,380) & \$ 3,450 & \$ 5,130\end{array}$

$\$ 5,130$

$\begin{array}{llllll}(\$ 15,835) & (\$ 4,257) & (\$ 13,637) & (\$ 10,187) & (\$ 5,057) & \$ 73\end{array}$

Net Revenue ( $\$ 000)$

Net revenue this phase

Cumulative net revenue

Note:

(1) Includes the area containing the former breeder reactor excavation. Assumes the existing excavation would be landscaped or reclaimed only as needed to satisfy a specific project. No speculative work to this end is included herein, thus no costs are shown. 
The high cost to the user is quite dramatically demonstrated in the previous table. The total cost of developing the site excluding any cost to landscape or reclaim the existing excavation is estimated to be $\$ 34,697,000$. If this expense is to be recouped through land sale revenues over time, then the selling price of the land must average approximately $\$ 57,000$ per acre.

\section{Alternative Investment Strategy}

The high selling price of $\$ 57,000$ per acre dictated by the base development scenario above, would have important negative consequences for marketing the site as noted in the previous section of this report. The level of infrastructure considered in the analysis is not excessive by today's standards, and cannot be significantly reduced to the point that it would alleviate the high cost. Highway and rail access to the site, for example, cannot be reduced regardless of the site size or development configuration that is selected. These costs remain relatively fixed.

The cause of the problem lies in part with the onsite topography and configuration, specifically:

- Infrastructure, rather than being extended in a straight line (the shortest distance between two points), must be extended laterally or branch-like to reach the developable tracts on this irregular site.

- Developable terrain is not contiguous and necessitates long runs to reach the sites that are usable, through undevelopable land.

- Developing large sites requires leveling large tracts of sloping or hilly topography.

Recognizing this, the solution is to reduce the cost of site preparation and reduce the linear infrastructure. This can be achieved by a program which avoids reclaiming the existing breeder site excavation, significantly reduces other grading programs, and focuses development exclusively on the main portion of the site for the time being, and avoiding "outlying areas" onsite.

This would produce the following project profile:

- Approximately 150 acres of industrial land would be opened to development in the vicinity of the former breeder reactor site.

- Approximately 375 acres of sellable land might be marketed.

- The tract could be developed for four or five sites at different elevations.

- Rough grading would be restricted to a total of about 65 acres confined to building pads and associated areas on land that is already graded or gradually sloping 
without significant topography. Average cost is $\$ 30,000$ per acre, or approximately $\$ 1,950,000$.

- Initially, site work is undertaken for one speculative building site only.

- Other building sites are leveled as required by specific users.

- The onsite water storage tank and pump, and the offsite water supply system improvements and sewage treatment plant capacity expansion would remain essentially as described in the base scenario above.

This approach depends heavily upon smaller users, requiring 20 to 30 acres of land, with building requirements averaging approximately 250,000 square feet.

The lower investment costs associated with this strategy and the projected revenue stream from land sales are shown in the following tables.

Under this scenario the total investment cost of $\$ 16,027,000$ dictates a break-even land selling price of $\$ 44,000$ per acre, a reduction from the base scenario of about $23 \%$. 


\section{Alternative Investment Phases}

\begin{tabular}{|c|c|c|}
\hline Phase 1 & $\begin{array}{l}\text { Prior to a purchase agreement } \\
\text { with site user }\end{array}$ & $\begin{array}{l}\text { - Upgrade 4-lane access from site to State } \\
\text { Route } 58 \\
\text { - Construct onsite portion of road access to } \\
\text { primary site area } \\
\text { - Commission an environmental assessment } \\
\text { - Engineer rail spur and siding, prepare } \\
\text { display-quality maps showing } \\
\text { hypothetical site layout, e.g. } 500,000 \mathrm{sf} \\
\text { building }\end{array}$ \\
\hline Phase 2 & $\begin{array}{l}\text { At signing of purchase } \\
\text { agreement for any site }\end{array}$ & $\begin{array}{l}\text { - Grade the building area } \\
\text { - Construct onsite and offsite water supply } \\
\text { pumping stations and line from the K-25 } \\
\text { treatment plant } \\
\text { - Construct onsite and offsite rail } \\
\text { - Construct onsite and offsite sewer lines to } \\
\text { Bear Creek treatment plant } \\
\text { - Upgrade Bear Creek sewage treatment } \\
\text { plant } \\
\text { - Engineer rail service, as above, for another } \\
\text { site }\end{array}$ \\
\hline Phase 3 & $\begin{array}{l}\text { At signing of purchase } \\
\text { agreement for second site }\end{array}$ & $\begin{array}{l}\text { - Construct onsite road access to the second } \\
\text { building area } \\
\text { - Rough grade the building area } \\
\text { - extend rail, water, sewer to area } \\
\end{array}$ \\
\hline Phase 4 & $\begin{array}{l}\text { At signing of purchase } \\
\text { agreement for additional } \\
\text { site(s) }\end{array}$ & $\begin{array}{l}\text { - Construct onsite access road to the } \\
\text { third/fourth building area } \\
\text { - Extend water, sewer, rail to site areas }\end{array}$ \\
\hline
\end{tabular}




\section{Alternative Clinch Bend Investment Schedule}

$(\$ 000)$

\begin{tabular}{|c|c|c|c|c|c|}
\hline \multirow[t]{2}{*}{ Improvements } & & \multicolumn{4}{|c|}{ Investment Phase } \\
\hline & & Phase 1 & Phase 2 & Phase 3 & Phase 4 \\
\hline \multicolumn{6}{|l|}{ Site } \\
\hline Land Acquisition & $1,200 \mathrm{Ac}$ & 2,000 & & & \\
\hline \multirow[t]{3}{*}{ Rough Grading } & $20 \mathrm{Ac}$ & & 600 & & \\
\hline & $15 \mathrm{Ac}$. & & & 450 & \\
\hline & 15 Ac.., 15 Ac. & & & & 900 \\
\hline \multicolumn{6}{|l|}{ Utilities } \\
\hline \multirow[t]{3}{*}{ Water Service } & 20 Ac. & & 442 & & \\
\hline & $15 \mathrm{Ac}$ & & & 55 & \\
\hline & 15 Ac., 15 Ac. & & & & 55 \\
\hline \multirow[t]{3}{*}{ Wastewater Service } & $20 \mathrm{Ac}$ & & 1,630 & & \\
\hline & 15 Ac. & & & 140 & \\
\hline & 15 Ac., 15 Ac. & & & & 140 \\
\hline \multicolumn{6}{|l|}{ Natural Gas Service } \\
\hline \multicolumn{6}{|l|}{ Electric Power Service } \\
\hline \multicolumn{6}{|l|}{ Access } \\
\hline \multirow[t]{3}{*}{ Highway } & 20 Ac. & 2,930 & & & \\
\hline & $15 \mathrm{Ac}$. & & & 400 & \\
\hline & $15 \mathrm{Ac}$. & & & & 400 \\
\hline Rail - engineer & $20 \mathrm{Ac}$. & & & & \\
\hline Rail - construct & $20 \mathrm{Ac}$. & & 5,160 & & \\
\hline Rail - engineer & $15 \mathrm{Ac}$ & & & & \\
\hline Rail - construct & 15 Ac., 15 Ac. & & & 350 & 325 \\
\hline \multicolumn{6}{|l|}{ Environmental } \\
\hline Environmental Assessment & - & 50 & & & \\
\hline Total & & $\$ 4,980$ & $\$ 7,832$ & $\$ 1,395$ & $\$ 1,820$ \\
\hline Cumulative Investment & & $\$ 4,980$ & $\$ 12,812$ & $\$ 14,207$ & $\$ 16,027$ \\
\hline
\end{tabular}




\section{Alternative Costs and Land Sale Revenue}

\section{Phase 1 Phase 2 Phase 3 Phase 4}

Revenue from Land Sales

Effective plant site (graded acres)

Acres in total tract sold

Selling price/acre $(\$ 000)$

Revenue this phase $(\$ 000)$

Cumulative revenue

Investment $(\$ 000)$

This phase

Cumulative investment

Revenue ( $\$ 000)$

Net revenue this phase

Cumulative net revenue

$\begin{array}{rrrrr} & 20 & 15 & 15 & 15 \\ & 115 & 85 & 85 & 85 \\ & \$ 44 & \$ 44 & \$ 44 & \$ 44 \\ \$ 0 & \$ 5,060 & \$ 3,740 & \$ 3,740 & \$ 3,740 \\ \$ 0 & \$ 5,060 & \$ 8,800 & \$ 12,540 & \$ 16,280\end{array}$

$\$ 4,980 \quad \$ 7,832 \quad \$ 1,395 \quad \$ 1,820 \quad \$ 0$

$\$ 4,980 \quad \$ 12,812 \quad \$ 14,207 \quad \$ 16,027 \quad \$ 16,027$

$\begin{array}{lllll}(\$ 4,980) & (\$ 2,772) & \$ 2,345 & \$ 1,920 & \$ 3,740\end{array}$

\begin{tabular}{lllll}
$(\$ 4,980)$ & $(\$ 7,752)$ & $(\$ 5,407)$ & $(\$ 3,487)$ & $\$ 253$ \\
\hline
\end{tabular} 